\title{
Radioluminescent Lighting for Alaskan Runway Lighting and Marking
}

\author{
G. A. Jensen \\ L. E. Leonard
}

March 1985

Work Supported by

the U.S. Department of Energy under Contract DE-AC06-76RLO 1830, the U.S. Department of Defense, and the State of Alaska

Pacific Northwest Laboratory Operated for the U.S. Department of Energy by Battelle Memorial Institute 


\title{
DISCLAIMER
}

This report was prepared as an account of work sponsored by an agency of the United States Government. Neither the United States Government nor any agency thereof, nor any of their employees, makes any warranty, express or implied, or assumes any legal liability or responsibility for the accuracy, completeness, or usefulness of any information, apparatus, product, or process disclosed, or represents that its use would not infringe privately owned rights. Reference herein to any specific commercial product, process, or service by trade name, trademark, manufacturer, or otherwise, does not necessarily constitute or imply its endorsement, recommendation, or favoring by the United States Government or any agency thereof. The views and opinions of authors expressed herein do not necessarily state or reflect those of the United States Government or any agency thereof.

\author{
PACIFIC NORTHWEST LABORATORY \\ operated by \\ BATTELLE \\ for the \\ UNITED STATES DEPARTMENT OF ENERGY \\ under Contract DE-AC06-76RLO 1830
}

\begin{tabular}{|c|c|}
\hline \multicolumn{2}{|c|}{ Printed in the United States of America } \\
\hline \multirow{2}{*}{\multicolumn{2}{|c|}{$\begin{array}{l}\text { Available from } \\
\text { National Technical Information Service }\end{array}$}} \\
\hline & \\
\hline \multicolumn{2}{|c|}{$\begin{array}{l}\text { National Technical Information Service } \\
\text { United States Department of Commerce }\end{array}$} \\
\hline \multicolumn{2}{|c|}{5285 Port Royal Road } \\
\hline \multicolumn{2}{|c|}{ Springfield, Virginia 22161} \\
\hline \multirow{2}{*}{\multicolumn{2}{|c|}{$\begin{array}{l}\text { NTIS Price Codes } \\
\text { Microfiche } A 01\end{array}$}} \\
\hline & \\
\hline \multicolumn{2}{|c|}{ Printed Copy } \\
\hline & Price \\
\hline Pages & Codes \\
\hline $001-025$ & A02 \\
\hline $026-050$ & $\mathrm{~A} 03$ \\
\hline 051-075 & A04 \\
\hline $076-100$ & $A 05$ \\
\hline $101-125$ & A06 \\
\hline $126-150$ & A07 \\
\hline $151-175$ & $A 0 B$ \\
\hline $176-200$ & $\mathrm{~A} 09$ \\
\hline $201-225$ & A010 \\
\hline $226-250$ & A011 \\
\hline $251-275$ & A012 \\
\hline $276-300$ & A013 \\
\hline
\end{tabular}



G. A. Jensen
L. E. Leonard(a)

March 1985

Work Supported by

the U.S. Department of Energy

under Contract DE-AC06-76RLO 1830, the U.S. Department of Defense, and the State of Alaska

Pacific Northwest Laboratory

Richland, Washington 99352

(a) State of Alaska Department

of Transportation and

Public Facilities 


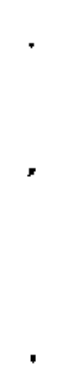

.

' 


\section{ACKNOWLEDGMENTS}

The help and support of the following individuals and their respective agencies have been important in developing civilian applications of radioluminescent airport lighting systems. We, therefore, wish to express our sincere thanks to the Alaska Air and Army National Guard, the North Carolina Army National Guard, and:

Les Everett Commander AASF $\#$ ], North Carol ina Army National Guard, Raleigh, North Carolina.

Neil Case Principal Investigator, Radioisotope Development and Applications, Oak Ridge National Laboratory, Oak Ridge, Tennessee.

Andy Tompkins Project Engineer, Oak Ridge National Laboratory, Oak Ridge, Tennessee.

Lyle Perrigo Manager, Battelle-Alaska Operations, Anchorage, Alaska.

Tom Hardy Project Officer, Air Force Engineering and Service Center, Tyndal? Air Force Base, Florida.

Bob Moles Engineer, Pacific Northwest Laboratory, Richland, Wash ington. 



\section{SUMMARY}

Alaska and other far northern areas have special logistical, environmental, and economic problems that make radioluminescent ( $R L$ ) lighting applications, especially in the area of airport lighting, an attractive alternative to electrical systems and flare pots. Tests and demonstrations of prototype systems conducted in Alaska over the past two years have proved the basic technological worth of RL airport lighting systems for civilian and military use. If regulatory issues and other factors identified during these tests can be favorably resoived and if the system and its components can be refined through production engineering, attractive applications for $R L$ airfield lighting systems in Alaska and other remote locations could result. 
. 


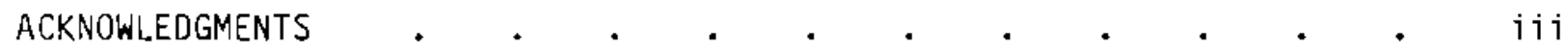

SUMMARY

INTRODUCTION

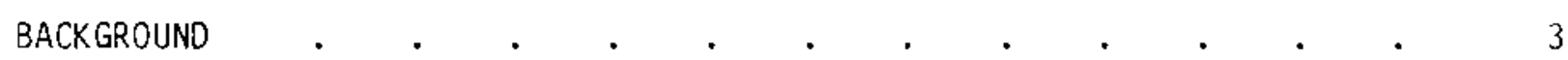

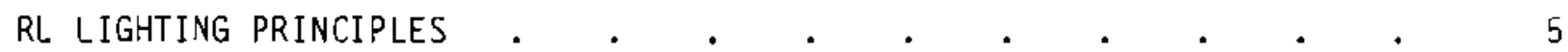

RL LIGHTING DEVELOPMENT AND APPLICATION IN ALASKA . . . . . . 7

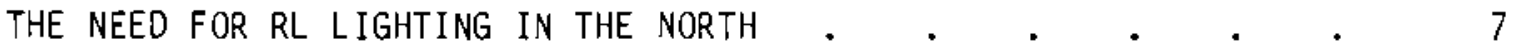

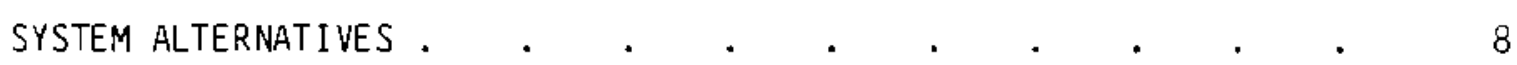

RL Lighting DEMONSTRATIONS AND EVALUATIONS . . . . . . . . 11

WINTER DEMONSTRATIONS AND TESTS . . . . . . . . 11

TAXIWAY LIGHTS AT FAIRBANKS INTERNATIONAL AIRPORT . . . . . 18

RL LIGHTING TESTS AT HANFORD ARID LANDS ECOLOGY RESERVE $\quad \cdot \quad \cdot \quad 19$

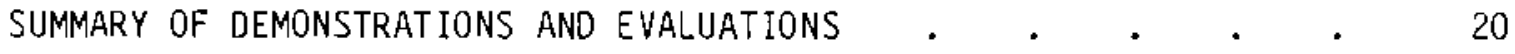

ISSUES AFFECTING RL LIGHTING SYSTEM USE IN ALASKA . . . . . . . $2 b$

$\operatorname{COST} \cdot \quad \cdot \quad \cdot \quad \cdot \quad \cdot \quad \cdot \quad \cdot \quad \cdot \quad \cdot \quad \cdot \quad \cdot \quad \cdot \quad 25$

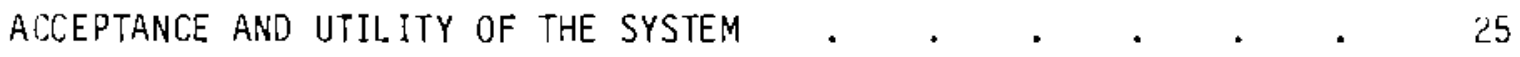

REGULATORY APPROVALS . . . . . . . . . . . . . . . 26

FEDERAL AVIATION REGULATIONS PART 135 APPROVAL $\quad . \quad$ • $\quad . \quad$. 27

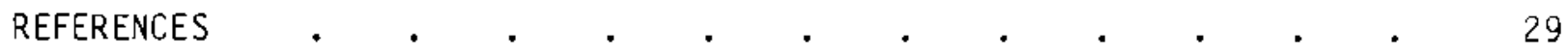

APPENDIX A - SUMMARY OF CIVILIAN PILOT RESPONSES - CENTRAL, ALASKA . A. 1

APPENDIX B - NEW YEAR'S EVE 1983 EVACUATION CORRESPONDENCE . . . . B.T

APPENDIX C - PHOTOGRAPHIC EVALUATION ACTION PLAN . . . . . . . . . C.l 


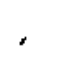

.

.

,

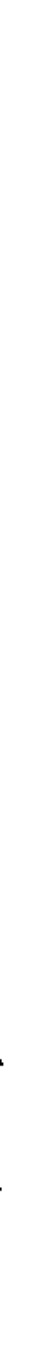


FIGURES

1 Technical Principle of Radioluminescent Lighting . $\quad$. 5

2 Radioluminescent Lighting Panel . . . . . . . . . . 12

3 Radioluminescent Superwand . . . . . . . . . . . 12

4 Radiolumines cent Wand . . . . . . . . . . . 13

5 Military Runway Configuration . . . . . . . . . . . . 15

6 Civilian Runway Configuration Tested at Central, Alaska . . 15

7 Visual Approach Slope Indicator . . . . . . . . . . . . lo

8 Radioluminescent Light Wind Indicator . . . . . . . . 17

9 Configurations of Glide Slope Indicators Evaluated . . . . 19

10 Light Fixture Evaluated Near Richland, Washington . . . . 20

11 Typical Photograph Taken at a Distance of 0.33 Mile from RL-Lighted Runway . . . . . . . . . . . . . 22

12 Typical Photograph Taken at a Distance of 0.77 Mile from RL-Lighted Runway . . . . . . . . . . . 22

13 Typical Photograph Taken at a Distance of 1.0 Mile from RL-Lighted Runway . . . . . . . . . . . 23

14 Typical Photograph Taken at a Distance of 1.5 Miles from RL-Lighted Runway . . . . . . . . . . . 23

15 Typical Photograph Taken at a Distance of 1.9 Miles from RL-Lighted Runway . . . . . . . . . .

$\underline{\text { TABLES }}$

1 Possible I sotopes for Self-Powered Illuminators and Relevant Properties . $\quad . \quad$. $\quad . \quad$. . . . . . 6

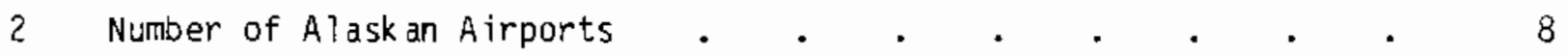

3 Summary of Military and Civilian Test Program in Alaska . . . 14

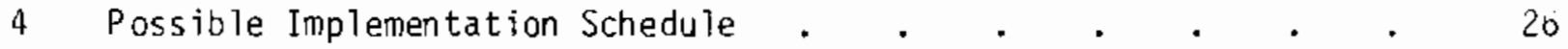





\section{INTRODUCTION}

Alaska has a Iand area greater than one fifth that of the contiguous 48 states and a population that concentrates in urban areas such as Fairbanks and Anchorage. However, a significant portion of its population is sparsely scattered throughout the state in small towns, villages, camps, and outposts. These pockets of habitation exist for a variety of reasons: native American traditions, resource development and expioration, and government agency and military requirements. All rural Alaskans have one thing in common: they are at the extreme end of the ration's supply line for goods and services. This separation from the greater economic infrastructure of the nation and the nature of the environment place special demands on the equipment, facilities, and systems installed and used in rural Alaska.

A? though similar conditions exist at other U.S. locations, design, construction, and maintenance of federal, state, and privately owned facilities are much more complex and expensive in Alaska. Therefore, a constant effort is required to develop or identify technologies and improve the means and methods that allow users to keep pace with public expectations for increased levels of services and facilities across the state. Radioluminescent (RL) lighting is such a technology. Strong potential also exists in expanding the use of RL lighting to the military in remote, austere, and tactical applications where utility or portable electrical power is unavailable or difficult to obtain. $(1,2)$ Research and development incentives for both military and civilian uses have been identified, and development work to provide lighting that meets these needs is under way.

This research is sponsored by the U.S. Department of Energy (DOE), U.S. Department of Defense (DOD), and State of Alaska Department of Transportation and Public Facilities (DOT\&PF). (1-3) A technical working group (TWG) has been formed to aid $D O E$ in ensuring that the objectives of the various interests are met. Membership in the TWG is by invitation and consists of the DOEHeadquarters program manager, who chairs the TWG, representatives from 
participating DOE raboratories, (a) DOD user agencies, the Alaska DOT\&PF, and other users and interested parties.

The purpose of the work reported here is to describe the potential for RL lighting applications in Alaska and to discuss the demonstrations and tests that have been completed in Alaska. Alaskan needs, primarily those of the civilian sector, will also be discussed. Since military needs parallel those of the civilian sector, they will be addressed only as required to provide. clarity in the discussion or when they differ substantially from the civilian requirements.

(a) Pacific Northwest Laboratory (PNL), Richland, Washington, is operated for DOE by Battelle Memorial Institute; and Oak Ridge National Laboratory (OR NL), Oak Ridge, Tennessee, is operated for DOE by the Martin Marietta Company. 


\section{BACKGROUND}

In the decade following Alaskan statehood in 1959, the population of Alaska began to rise significantly. The influx concentrated in urban areas, primarily around the $0 i 1$ and gas activity of the Cook Inlet area. When oil was discovered on the North Slope of Alaska in 1968, a new growth spurt occurred, prompting a closer investigation of technologies that couid be used in the more remote parts of the state. Meanwhile, most rural commuities continued to remain primitive and isolated from the rest of the state.

In the 1970s, two major factors drastically altered the complexion of rural Alaska: 1) the Alaska Native Land Claims Settlement Act of 1971 and 2) the construction of the TransAlaska Pipeline and the bringing of the Prudhoe Bay oil field into production. The result was that by 1980 rural Alaskans were politically and economically alert, demanding and receiving increased levels of sophisticated public services and facilities funded and sustained with state $0 i 1$ revenues and receipts from local and regional native corporations. Rural residents were more affiuent and mobile, often traveling both between rural commities and to and from urban centers.

The 1980s were barely under way when world oil prices produced a windfall for state revenue. Initially this situation promised to be the case for the long term; today, however, Alaska faces a declining revenue forecast resulting from the international $0 i 1$ glut and the inevitability of depletion of the Prudhoe 8ay field and lowered expectations of the resource. At the same time, the events of the past few years have created high public expectations for sophisticated public facilities and services, especially in rural Alaska, which in many ways has just begun to merge into the mainstream of U.S. economic and social activity.

With these considerations in mind, the providers of capital improvements and those who will maintain those improvements and the existing inventory of state- and federal-owned facilities must be very selective in use of dollars. State govermmental organizations are attempting to meet this challenge by identifying and, where necessary, developing new technologies such as RL 
lighting that will lead to the more efficient use of resources while continuing to improve the quality of public facilities and services. 


\section{RL LIGHTING PRINCI PLES}

The fact that radiation produced from radioisotopes can be used to excite phosphors that, in turn, emit visible light has been known for many years. $(1,4,5)$ Beta particles (electrons) are produced by the selected isotope during its decay to form another element. These electrons strike a phosphorescent material, such as zinc sulfide, that contains a small quantity of impurity, such as copper, silver, or cadmium, and are absorbed. Light is produced when the energy from this absorption is released (Figure 1). Other forms of radiation can also be produced during the decay process; for example, alpha particles, neutrons, and gamma rays. Alpha particles are helium nuclei, which are emitted at high velocity. Gamma rays are a form of electromagnetic radiation similar to $x$-rays but with a higher frequency and greater penetrating power, requiring shielding. If an isotope is to have a practical value as an energy source for self-powered lights, it should have the following characteristics:

- a relatively long half-life

- no emission of alpha particles, neutrons, or gamma rays or be easily shiel ded

- production of a stable daughter; for example, a nonradioactive isotope

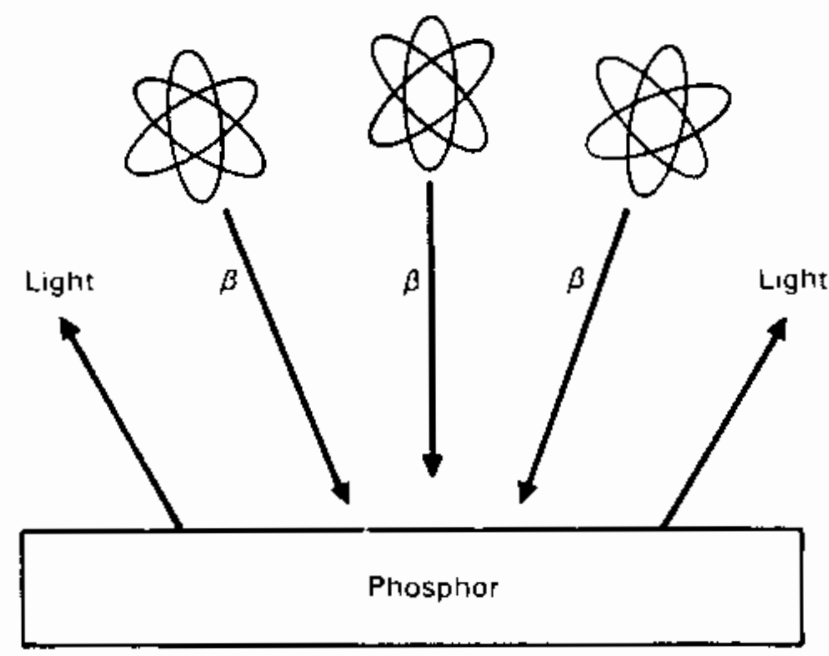

FIGURE 1. Technical Principle of Radioluminescent Lighting (gas - tritium or krypton-85; solid - promethium) 
- low chemical and radiological toxicity

- a modest or law cost.

I sotopes that could meet these requirements are listed in Table 1. Krypton-85 and promethium- 147 have only been used in special applications and test situations. Tritium meets all of the above requirements and is, therefore, used in a variety of commercially available products in various applications.

Tritium gas can be encapsulated in a glass tube or container coated on the inside with a zinc sulfide phosphor. Uses for this type of light source in-. clude exit and other self-powered warning signs for buildings, aircraft, and light standards in the photographic industry. For example, lights containing from 4 to 30 curies of tritium have been used on commercial aircraft and in public buildings in emergency exit signs since the mid-1960s. (3) The primary advantages of RL lighting are:

- The lighting requires no external source of power; thus, it is not subject to power failure or interruption.

- The lighting does not burn out or require wiring; thus, the units are self-contained and maintenance is minima?.

- Supply problems from short shelf life component replacement, such as batteries, are reduced where temporary or emergency lighting is required.

- The lighting can function under many severe environmental conditions such as temperatures below $-70^{\circ} \mathrm{F}$.

\section{TABLE 1. Possible Isotopes for Self-Powered Illuminators and} Relevant Properties (a)

\begin{tabular}{|c|c|c|c|c|c|c|}
\hline I sotope. & $\begin{array}{l}\text { Half-Life, } \\
-y T \\
\end{array}$ & $\begin{array}{l}\text { Maximum Beta } \\
\text { Energy, Mev }\end{array}$ & $\begin{array}{l}\text { Gamma Ray, } \\
\end{array}$ & $\begin{array}{l}\text { Cnemical } \\
\text { Toxicity }\end{array}$ & $\begin{array}{l}\text { Radiological } \\
\text { Toxicity }\end{array}$ & Remarks \\
\hline Iritium $\left\{\mathrm{H}^{3}\right\}$ & 12.4 & 0.018 & nil & nil & very low & $\begin{array}{l}\text { Low energy. ldeal for luainous } \\
\text { paint. Low cost. Easy to } \\
\text { handle. No snielding beyona } \\
\text { containment required. }\end{array}$ \\
\hline Prome th ium- 147 & 2.6 & 0.23 & nil & nil & medium & $\begin{array}{l}\text { Expensive. Short nalf-iife. } \\
\text { Contaminating gamm ray emitting } \\
146 p m \text { and } \\
480 m p m \text { present. }\end{array}$ \\
\hline Krypton- 85 & 10.7 & 0.67 & $\begin{array}{l}0.5 \% \text { of } \\
0.5 \mathrm{MeV}\end{array}$ & nil & iow & $\begin{array}{l}\text { Inert gas. Some snielding re- } \\
\text { quired. Expensive. Encapsula- } \\
\text { tion can discolor because of } \\
\text { radiation. }\end{array}$ \\
\hline
\end{tabular}

(a) See References 3 and 6 . 


\section{RL LIGHTING DEVELOPMENT AND APPLICATION IN ALASKA}

The research conducted to date has identified the following areas where RL lighting could be of practical use in civilian facilities and military operations:

- signs and markers in buildings

- signs and markers in highway, roadway, harbor, and coastal marine applications

- obstruction markers for emergency and construction applications

- obstruction markers for aviation

- airport signs, markers, and airfield edge and threshold lighting (both marine and terrestrial)

- aircraft landing aids

- other military applications.

of the uses listed above, only the last three have received serious investigation by military and civil organizations in Alaska. This is not because the other applications are less important but because airfield lighting is currently a critical issue. For the state, self-powered lighting has a foreseeably significant economic impact on state-owned airfields, the aviation industry, and the public. For the military, it has a major benefit in meeting tactical and emergency airfield needs. Efforts have therefore concentrated on airfield lighting as it would be applied in rural or tactical airfields. The intent is to implement the airfieid lighting systems before other applications are fully investigated.

THE NEED FOR RL LIGHTING IN THE NORTH

In the winter many of the land- and water-based transportation routes in Alaska (and the Arctic) become impassable. For much of the North, air transportation becomes the only alternative. Winter weather and the short amount of daylight at high latitudes severely limit the hours that commercial or military aircraft can operate at unlighted runways, and only a small fraction of 
existing runways are lighted (Table 2). As a result, commerciai carriers must have more aircraft and more pilots available to operate during the limited daylight hours or unreliable batteries or power systems must be used at tactical military airfields during field operations or emergency conditions. These factors severely raise costs and put added pressure on civilian or military operations and pilots to complete missions in marginal conditions. Inefficiency and safety could be significantly improved if more civilian airfields and tactical runways were equipped with self-powered lights. Ground maintenance and operations are also affected by equipment and batteries that fail in the cold.

\section{SYSTEM ALTERNATIVES}

Currently, two types of lighting are commoniy used to aid commercial night operations in Alaska:

- The Federal Aviation Administration (FAA)-approved medium-intensity runway lighting (MIRL) or high-intensity runway lighting (HIRL) as

\section{TABLE 2. Number of Alaskan Airports}

\section{Land-Based}

Lighted airports operated by DOT\&PF

Lighted airports operated by military and Coast Guard

Lighted airports operated by others

Total number of Tignted airports

Airports operated by DoT\&PF

Total number of general aviation airports 685

Total number of airports operated by military and Coast Guard 67 Total number of land-based airports 752 Land- and Sea-Based

Total number of airports in Alaska $\quad \sim 1,000$ 
described in FAA Advisory Circular \#AC 150/5340-24. These lighting systems include electric incandescent runway edge and threshold lights, blue taxiway lights, a rotating locator beacon, and a lighted wind direction indicator.

- Flare pots or lanterns for night Visual Flight Rules (VFR) for only nonpassenger-carrying commercial aircraft--Part 91 of the Federal Aviation Regulations (FAR)--or under special permission granted a carrier by FAA under Part 135.229 of the FAR if passengers are aboard. This system consists of flare pots or lanterns spaced at 400-ft intervals along both edges of the runway and some means of communicating wind direction information to the pilot.

MIRL and HIRL systems are specified in detail and can only be modified by special waiver from the FAA in washington, D.C. The use of flare pots and 1 anterns is interpreted more loosely by the regulators and $c$ an be modified with in the jurisdiction of a particular region of FAA, such as the Alaskan region. Permanent military airfields have requirements similar to those of the FAA for HIRL and MIRL. Two additional portable systems are available for tactical or emergency use:

- Battery-powered beanbag lights are compact and can be placed as required on the runway.

- Portable hand-wired runway lighting systems are powered by conventional diesel- or gasoline-fueled generators. The lights are mounted on stakes and placed along the runway as required. Exposed wires suffer damage in arctic weather.

As an alternative civilian and portable military system, RL lighting consisting of RL edge and threshold lights, blue RL taxiway lights, RL visual approach slope indicators, and RL-lighted wind direction indicators has been evaluated. The implementation strategy for using the RL system in Alaska is:

1. Use of the RL system would begin at selected presently unlighted rural runways as an alternative to flare pots or lanterns (under Parts 91 and 135 of the FAR) or at tactical runways in place of beanbag lights or portable systems. After a period of satisfactory use in Alaska, the 
users would probably seek federal approval to use RL systems as substitutes for MIRL systems.

2. When the RL system has gained full FAA acceptance, the state would accelerate its installation rate at unlighted airports and begin replacing particularly troublesome electric systems. As existing electric systems reached the practical limit of their life cycles, the state would make further replacements with RL lighting systems, working toward eventual standardization of the RL lighting system. Military use of the RL system would also expand in parallel as more systems became available. 


\section{RL LIGHTING DEMONSTRATIONS AND EVALUATIONS}

The following sections illustrate the results of demonstrations and evaluations of RL lighting systems that were conducted during the winter of 1983-84 and the following summer at several locations in Alaska and near Richland, Wash ington.

\section{WINTER DEMONSTRATIONS AND TESTS}

The iterative process of design modification of tritium-powered RL systems for airfield lighting and marking that began in 1982 has produced a prototypic system for use at tactical military airfields and rural Arctic and sub-Arctic airfields. This system resulted from several short-term civilian and military evaluations in Alaska and a long-term civilian evaluation at Central, Alaska, during the winter of 1983 and 1984.

RL lighting panels, superwands, and wands used in these tests are shown in Figures 2, 3, and 4. The lighting panels and superwands incorporated a new tritium tube design that was developed by ORNL during 1983 in response to the need for greater brightness identified during tests and evaluations conducted at the "Brimfrost 83" exercises. (7) Preliminary design of the support fixtures and hardware was initiated by Alaska DOT\&PF and PNL personnel and finalized at ORNL.

Evaluations using a prototype of the panel as the basic light element and supporting fixtures were made at Camp Macka11, North Carolina, during the fall of 1983. Observers and pilots reported they could see the lights from 4 to 6 miles. The omnidirectional superwand (Figure 3) was developed during this period and represents an improvement over the first-generation wand used during "Brimfrost 83" testing (Figure 4). (7) Since response to the panel and superwand was good, the lights were brought to Alaska for winter tests and evaluation.

A military and civilian test program was conducted in Alaska from November 19, 1983, through February 19, 1984 (Table 3). At the end of the test, the lights were removed from Central, Alaska, to Anchorage and returned to the "lower 48" for further testing. 


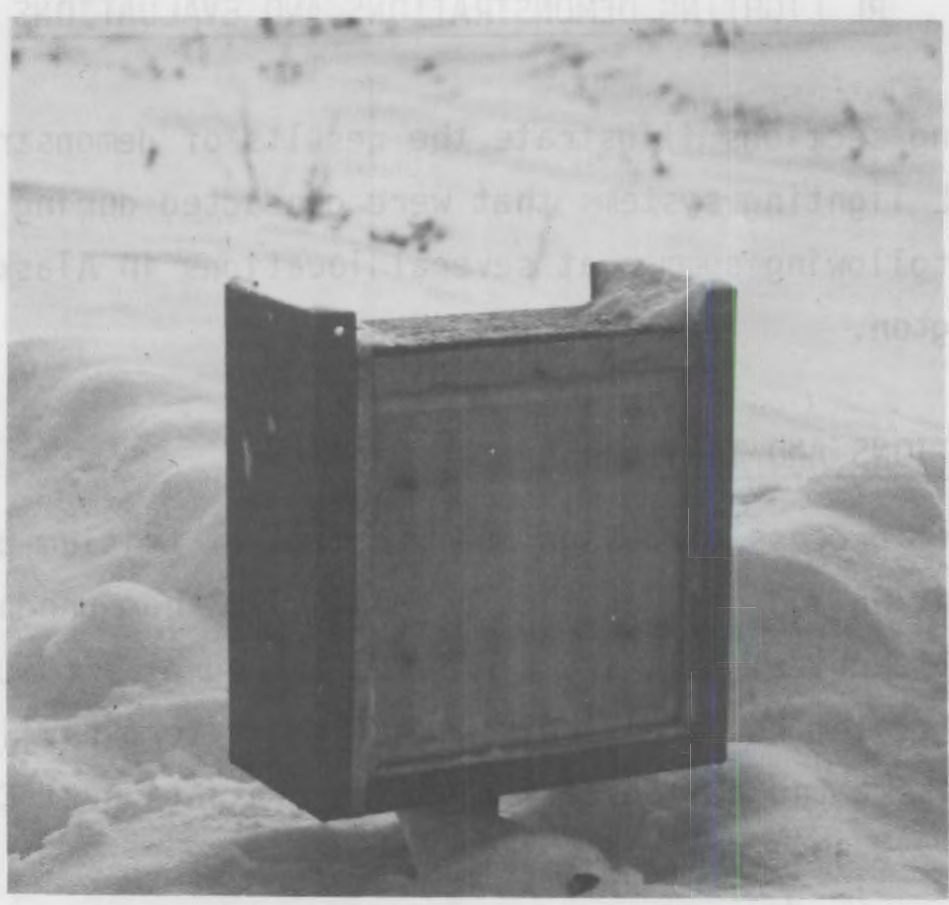

FIGURE 2. Radioluminescent Lighting Panel

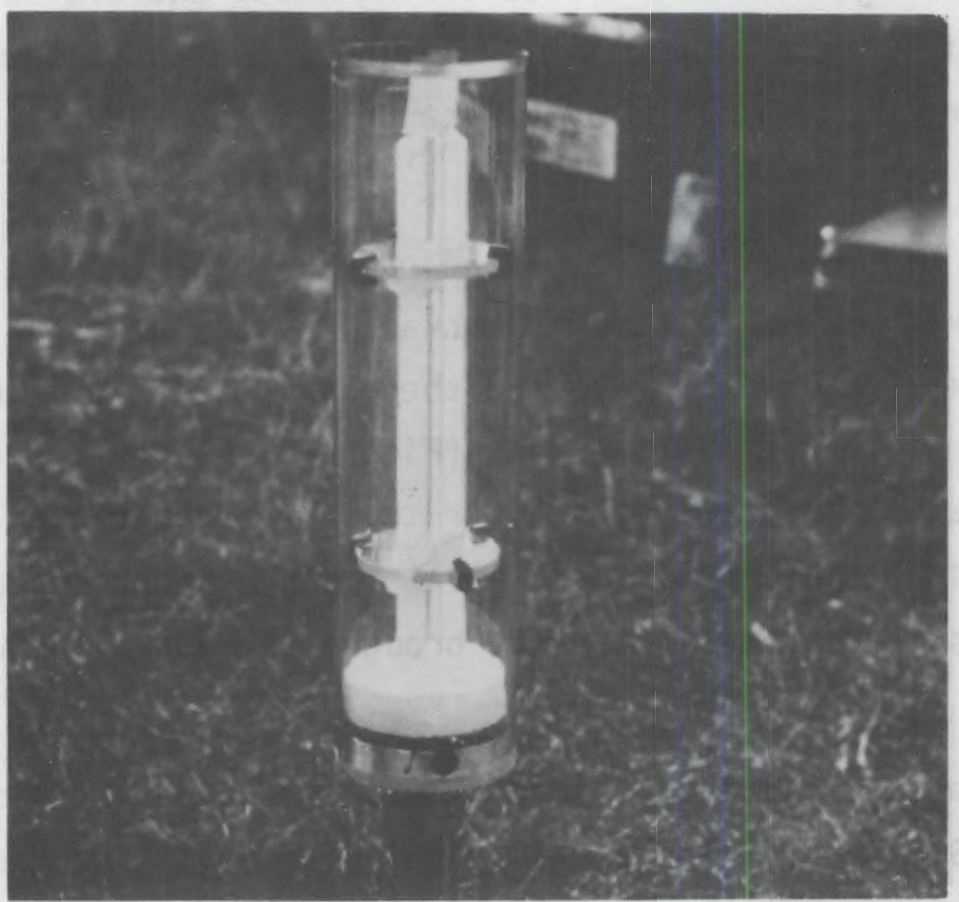

FIGURE 3. Radioluminescent Superwand 


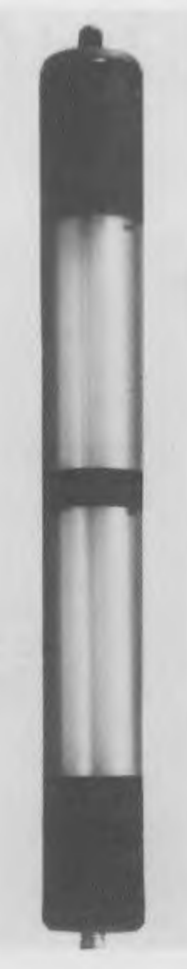

FIGURE 4. Radioluminescent Wand

The lights were installed at several locations for military evaluation. (a) The basic configurations of the lighting system used in these tests are shown in Figures 5 and 6 . Both configurations were modified periodically by increasing or decreasing the number of lights in the threshold area to determine where the pilot sees the lights (acquisition) and can define (use) the lights or landing aids. Since these evaluations were primarily for military use of the lights, most of the flying was done with the runway configured as shown in Figure 5. This configuration is designed to meet Military Airlift Command regulations for nighttime operations. Military pilots reported they were able to see the lights from 3 to 6 miles distant and found the runway marking usable for alignment and landing from 2 to 6 miles away. Some difficulty was experienced

(a) Alaskan Air Command (AAC) report, Improved Tritium Radioluminescent Lighting, February 1984, prepared by L. J. Hult, Major, U.S. Air Force Chief, Operations Services Division, and C. L. Bupp, Captain, U.S. Air Force Chief, Maintenance Management and Industrial Engineering Division, issued by HQ AAC/DOOS, Elmandorf Air Force Base, Alaska 99506. 
TABLE 3. Sumary of Military and Civilian Test Program in Alaska (November 19, 1983, to February 19, 1984)

\begin{tabular}{|c|c|c|c|c|c|c|c|c|c|c|c|}
\hline \multirow{2}{*}{$\begin{array}{c}\text { Test } \\
\text { Location } \\
\end{array}$} & \multirow{2}{*}{$\begin{array}{l}\text { Test } \\
\text { Date } \\
\end{array}$} & \multirow[b]{2}{*}{ Aircraft } & \multicolumn{2}{|c|}{ Sorties } & \multirow{2}{*}{$\begin{array}{c}\text { Runway } \\
\text { Configuration } \\
\end{array}$} & \multirow{2}{*}{$\begin{array}{l}\text { Acquisition } \\
\text { Distance, mi }\end{array}$} & \multicolumn{5}{|c|}{ Weather } \\
\hline & & & Landings & Flyovers & & & Temp.. " & Wind & Visibility & Precipitation & Moon \\
\hline \multirow[t]{4}{*}{$\begin{array}{l}\text { Allen } \\
\text { Army } \\
\text { Airfield }\end{array}$} & Nov 19 & $\begin{array}{l}\text { Cessna } 208 \\
\text { C-12 } \\
U H-1\end{array}$ & $\begin{array}{c}8-10 \\
1 \\
1-4\end{array}$ & - & Civilian & $\begin{array}{l}1-3 \\
3-4 \\
2-3 \frac{1}{2}\end{array}$ & $-9^{\circ} \mathrm{F}$ & $\begin{array}{l}\text { Light and } \\
\text { variable }\end{array}$ & $\begin{array}{l}\text { Clear } \\
15+\text { miles }\end{array}$ & 0 & Full \\
\hline & $\begin{array}{l}\text { Nov } 20 \text {, } \\
21\end{array}$ & $0-2$ & 0 & 2 & - & & Cold & $\begin{array}{l}\text { High } \\
\text { turbulence }\end{array}$ & Clear & 0 & Full \\
\hline & Nov 22 & $\begin{array}{l}0-2 \\
c-12\end{array}$ & $\begin{array}{c}\text { Several } \\
2\end{array}$ & $\begin{array}{l}\text { Numerous } \\
\text { Numer ous }\end{array}$ & Military & $\begin{array}{l}4-5 \\
4-6\end{array}$ & Cold & High & $\begin{array}{l}\text { Partly } \\
\text { cloudy }\end{array}$ & 0 & Full \\
\hline & Nov 23 & $\begin{array}{l}\text { Cessna } 20 B \\
C-130\end{array}$ & $\begin{array}{l}2-4 \\
8-10\end{array}$ & - & Military & $2_{2-3}^{\frac{1}{2}}(a)$ & Cold & None & Cloudy & $\begin{array}{l}\text { Snowing } \\
\text { hard }\end{array}$ & -- \\
\hline \multirow{3}{*}{$\begin{array}{l}\text { Donnally } \\
\text { Landing } \\
\text { Zone }\end{array}$} & $\begin{array}{l}\text { Nov } 28 \\
\text { Nov } 29\end{array}$ & $\begin{array}{l}\text { Flying } \\
\text { cancelled }\end{array}$ & -- & -- & - & -- & $42^{\circ} \mathrm{F}$ & $40+\mathrm{mph}$ & Clouay & -- & -- \\
\hline & $\begin{array}{l}\text { Nov } 30 \\
\text { Dec } 1\end{array}$ & $\begin{array}{l}C-130 \\
C-130\end{array}$ & $\begin{array}{l}20 \\
30\end{array}$ & $=$ & $\begin{array}{l}\text { Military } \\
\text { Military }\end{array}$ & $\begin{array}{l}3-4(a) \\
3-4(a)\end{array}$ & $\begin{array}{l}40^{\circ} \mathrm{F} \\
40^{\circ} \mathrm{F}\end{array}$ & $20+\mathrm{mph}$ & Cloudy & -- & $\cdots$ \\
\hline & Dec 2 & $\begin{array}{l}\text { Flying } \\
\text { cancelled }\end{array}$ & None & 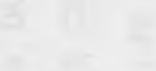 & & & $10-15^{\circ} \mathrm{F}$ & Light & Cloudy & $\begin{array}{l}\text { Heavy } \\
\text { snow }\end{array}$ & -- \\
\hline \multirow[t]{2}{*}{$\begin{array}{l}\text { Allen } \\
\text { Army } \\
\text { Airfield }\end{array}$} & Dec 5 & $A-10$ & 0 & $\begin{array}{l}15-20 \\
\text { miles }\end{array}$ & Military & $4+$ & $15^{\circ} \mathrm{F}$ & Calm & $15+$ miles & 0 & $\begin{array}{l}\text { Broken } \\
\text { cloud } \\
\text { cover }\end{array}$ \\
\hline & Dec 6 & $A-10$ & 0 & 24 miles & Military & $3-6$ & $15^{\circ} \mathrm{F}$ & $\begin{array}{l}17-20 \text { knots; } \\
\text { gusts to } \\
26 \text { knots }\end{array}$ & $10+$ miles & 0 & $\begin{array}{l}\text { Broken } \\
\text { cloud } \\
\text { cover }\end{array}$ \\
\hline $\begin{array}{l}\text { Eielsen } \\
\text { AF B }\end{array}$ & $\begin{array}{l}\text { Dec } 12 \\
\text { Dec } 13 \\
\text { Dec } 14\end{array}$ & $\begin{array}{l}A-10 \\
A-10 \\
A-10\end{array}$ & $\begin{array}{l}8-10 \\
8-10 \\
2-4\end{array}$ & $\begin{array}{l}25 \\
20-25 \\
10-15\end{array}$ & $\begin{array}{l}\text { Military } \\
\text { Several (b) } \\
\text { Several (b) }\end{array}$ & $\begin{array}{l}4+ \\
4+ \\
4+\end{array}$ & $\begin{array}{l}-30^{\circ} \mathrm{F} \\
-30^{\circ} \mathrm{F} \\
-30^{\circ} \mathrm{F}\end{array}$ & $\begin{array}{l}\text { Cain } \\
\text { Calm } \\
\text { Calm }\end{array}$ & $\begin{array}{l}15+\text { miles } \\
15+\text { miles } \\
15+\text { miles }\end{array}$ & $\begin{array}{l}0 \\
0 \\
0\end{array}$ & $\begin{array}{l}60 \% \text { moon } \\
70 \% \text { moon } \\
70 \% \text { moon }\end{array}$ \\
\hline \multirow[t]{4}{*}{$\begin{array}{l}\text { Central, } \\
\text { Alaska }\end{array}$} & $\begin{array}{l}\text { Dec } 19 \\
\text { Feb } 8\end{array}$ & $\begin{array}{l}\text { Several } \\
\text { Cessna } 206\end{array}$ & $\begin{array}{l}\text { Several } \\
2-3\end{array}$ & -- & $\begin{array}{l}\text { RL civilian } \\
\text { RL civilian }\end{array}$ & $\begin{array}{l}3-7 \\
3+\end{array}$ & $-34^{\circ} \mathrm{F}$ & $\begin{array}{l}\text { Varied } \\
\text { Calm }\end{array}$ & 15+ miles & Thin & $\begin{array}{l}\text { Quarter } \\
\text { moon }\end{array}$ \\
\hline & 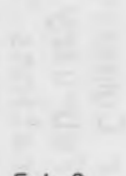 & Cessna 206 & $\begin{array}{l}2-3 \\
2-3\end{array}$ & & $\begin{array}{l}\text { RL civilian } \\
\text { Flare pot V } \\
\text { lead-in } \\
\text { RL civilian } \\
\text { Flare pot Y } \\
\text { lead-in }\end{array}$ & $3+$ & & & & & \\
\hline & Feb 9 & Cessna 206 & & & $\begin{array}{l}\text { RL civilian } \\
\text { RL lead-in }\end{array}$ & $\frac{11}{2}-2$ & $-34^{\circ} \mathrm{F}$ & Calm & 2 miles & Indefinate & $\begin{array}{l}\text { C loud } \\
\text { cover }\end{array}$ \\
\hline & Feb 15 & $\begin{array}{l}\text { Cessna } 206 \\
\text { Cessna } 206 \\
\text { Cessna } 206\end{array}$ & Several & ent & $\begin{array}{l}\text { RL civilian } \\
\text { VASI } \\
\text { Flare pots }\end{array}$ & $\begin{array}{l}2-4(c) \\
1 \frac{1}{2}-2 \\
(\text { us able) }(c) \\
4-5\end{array}$ & $-34^{\circ} \mathrm{F}$ & Calm & Unlimited & 0 & $\begin{array}{l}\text { Full } \\
\text { moon }\end{array}$ \\
\hline
\end{tabular}

a) C-130 pilots were only allowed to fly a short final approach and saw the lights upon turning to align with the runway.

(b) Primary purpose of these tests was to evaluate and attempt to improve acquisition of the visual approach slope indicator (VASI).

(c) Purpose of these tests was to evaluate several VASIs. 


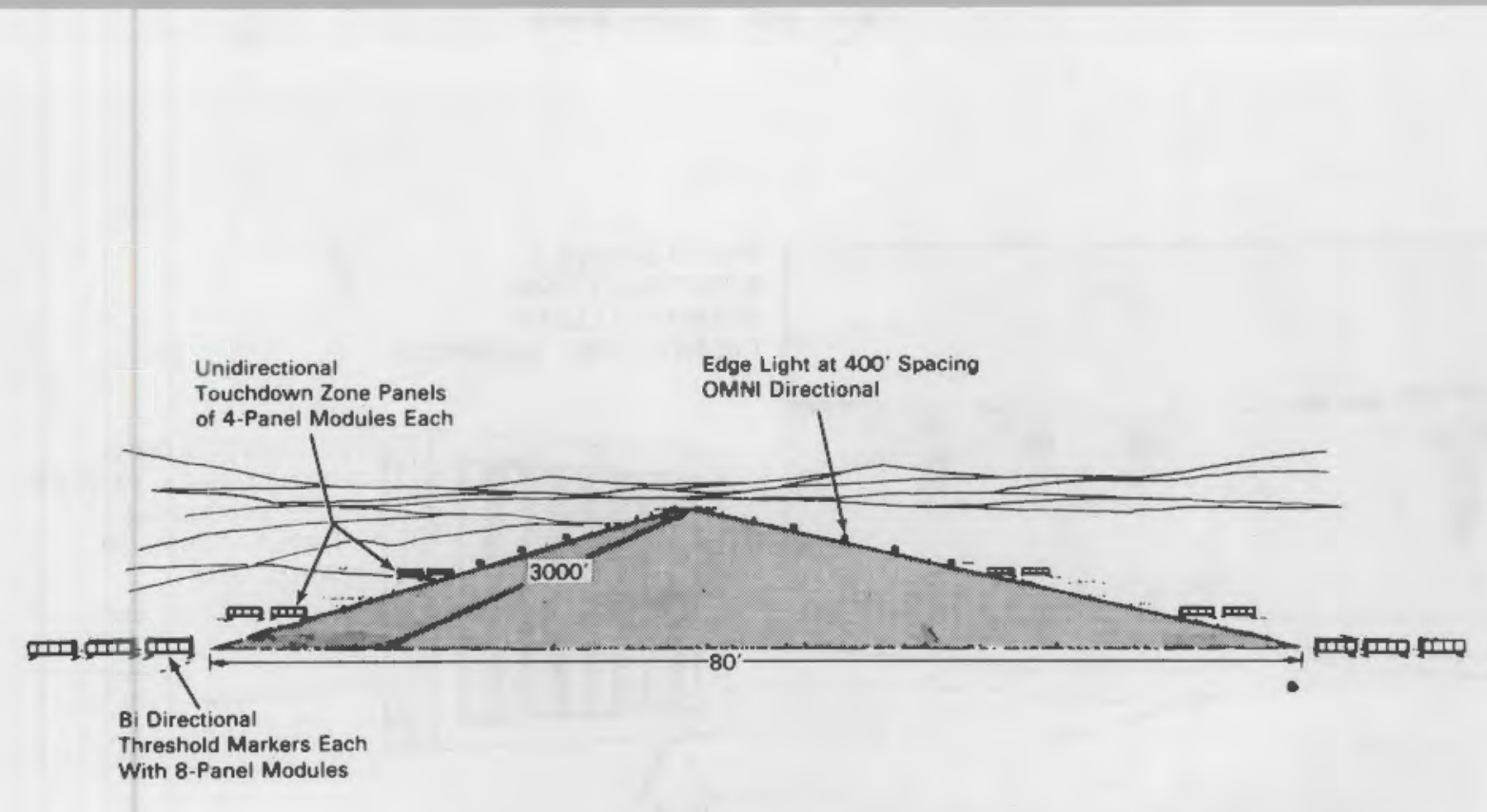

FIGURE 5. Military Runway Configuration

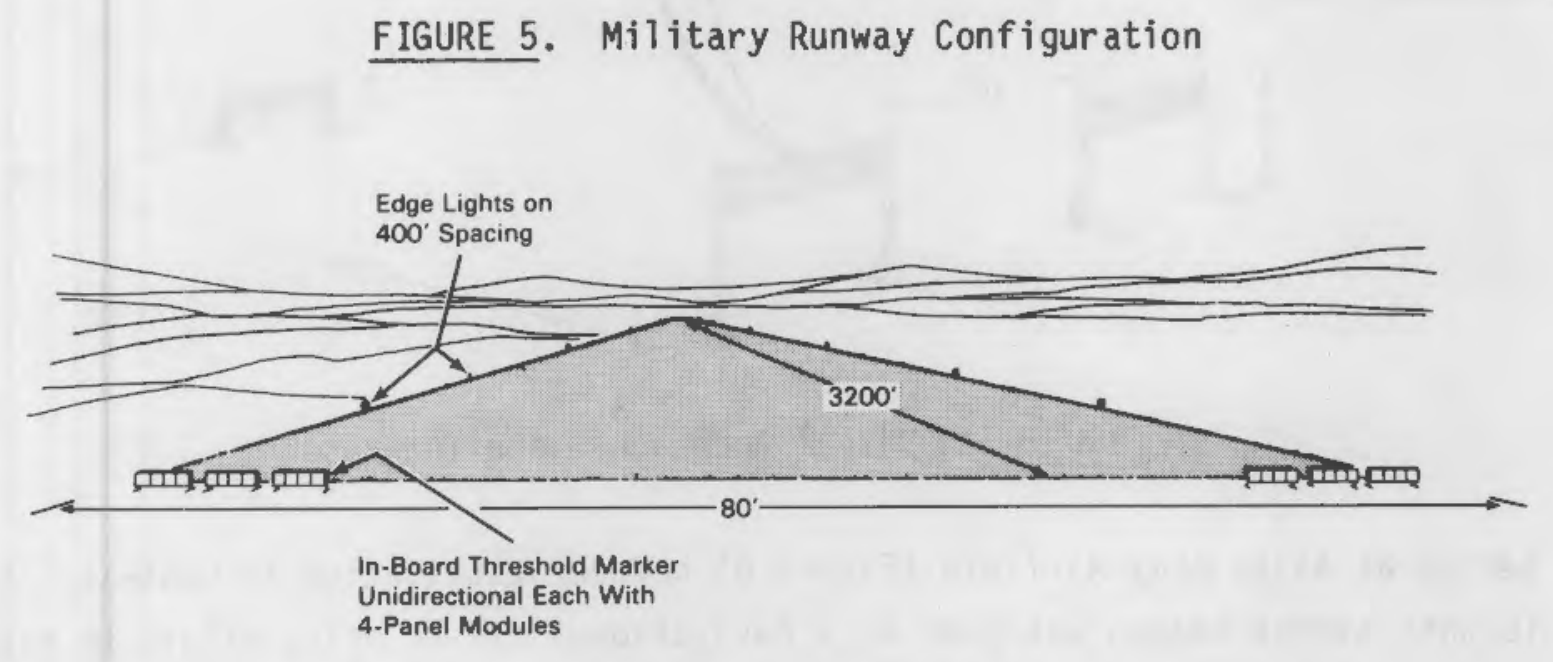

FIGURE 6. Civilian Runway Configuration Tested at Centra1, Alaska

by A-10 pilots during periods of high winds, but most felt that they could have landed to the lights under these conditions if they had been permitted to do so. $\mathrm{C}-130,0-2$, and $\mathrm{C}-12$ pilots reported no difficulty landing and generally rated the RL lighting satisfactory to outstanding. Many A-10 pilots also gave the lighting system an outstanding rating. On several occasions, a visual approach slope indicator (VASI), shown in Figure 7, was evaluated. Military pilots reported they could see the light from the VASI from 1 to 2 miles out but found it unusable. Attempts to increase the light output of this VASI did not improve the acquisition or usefulness of the system.

The lights were installed on the runway on December 19, 1983, at Central, Alaska, and were removed on February 21, 1984. The civilian configuration was 


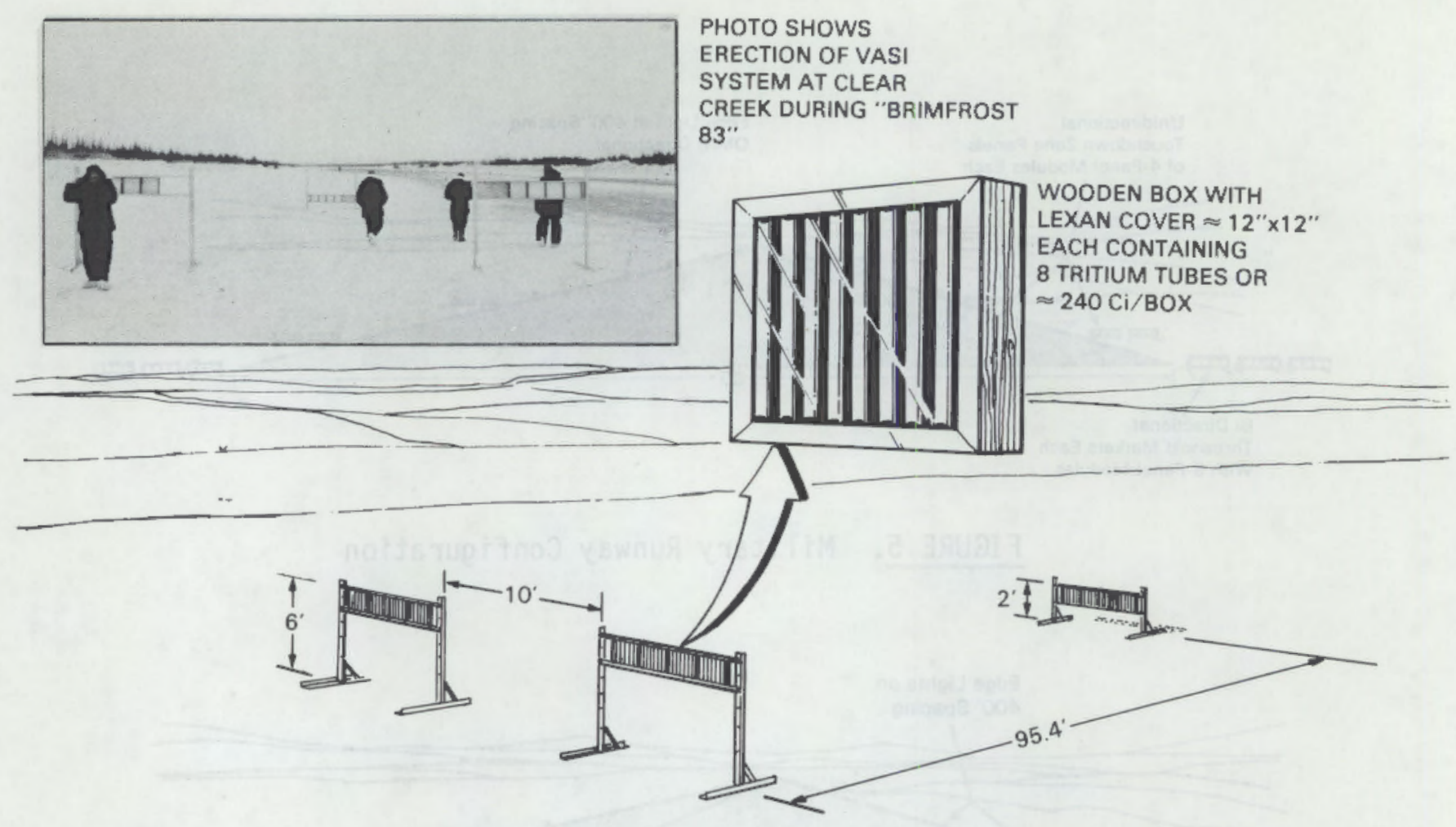

FIGURE 7. Visual Approach Slope Indicator

tested at Allen Army Airfield (Figure 6 ) before installation at Central. A 15-watt strobe beacon was used as a navigational aid to bring pilots to the general vicinity of the airfield. This beacon, powered by the 110-volt building power, was located on a DOT\&PF building approximately $1 / 4$ mile from the airfield. A RL glide slope indicator (Figure 7) and wind indicator (Figure 8) were also installed later in December. Evaluation questionnaires were provided to air taxi and other pilots $r$ andomly flying to the Central airstrip. A summary of the questionnaire returned for evaluation from pilots and passengers is presented in Appendix A. In general, the pilots reported that they could first see the runway from 2 to 5 miles away. Nominally, the acquisition distance averaged about 3 miles and visibility for alignment and landing was from 1 to 3 miles. The VASI was usable from a distance of $1 / 2$ to 1 mile, and the wind " $T$ " was unusable. There was an unplanned medical evacuation completed on New Year's Eve that would not have been possible without the RL runway lights. Correspondence relevant to the usefulness of RL lighting in this evacuation is presented in Appendix B. 
The test team and FAA flight standards personnel evaluated the RL runway lighting system and navigational and landing aids such as alignment or lead-in lights, strobe, flare pots as edge markers and lead-in lights, various VASI configurations, and combinations of these various landing aids. The flare pots were evaluated to determine whether they could be used to lead pilots to the airfield if the strobe failed. In all approaches, the RL runway lights were first seen from approximately 3-1/2 miles away, alignment was possible at 3 miles away, and positive runway definition occurred at approximately 2 to $2-1 / 2$ miles away. When visibility was reduced, acquisition and visibility of the lights were reduced proportionally. In clear weather, pilots normally had full $v$ ision of the runway at 2 miles. Flare pots worked well for runway alignment but were not judged as effective a navigational aid as the strobe. The strobe could be identified from 7 to 11 miles away compared with 4 to 5 miles for flare pots. The RL glide slope indicator (Figure 7) was normally not

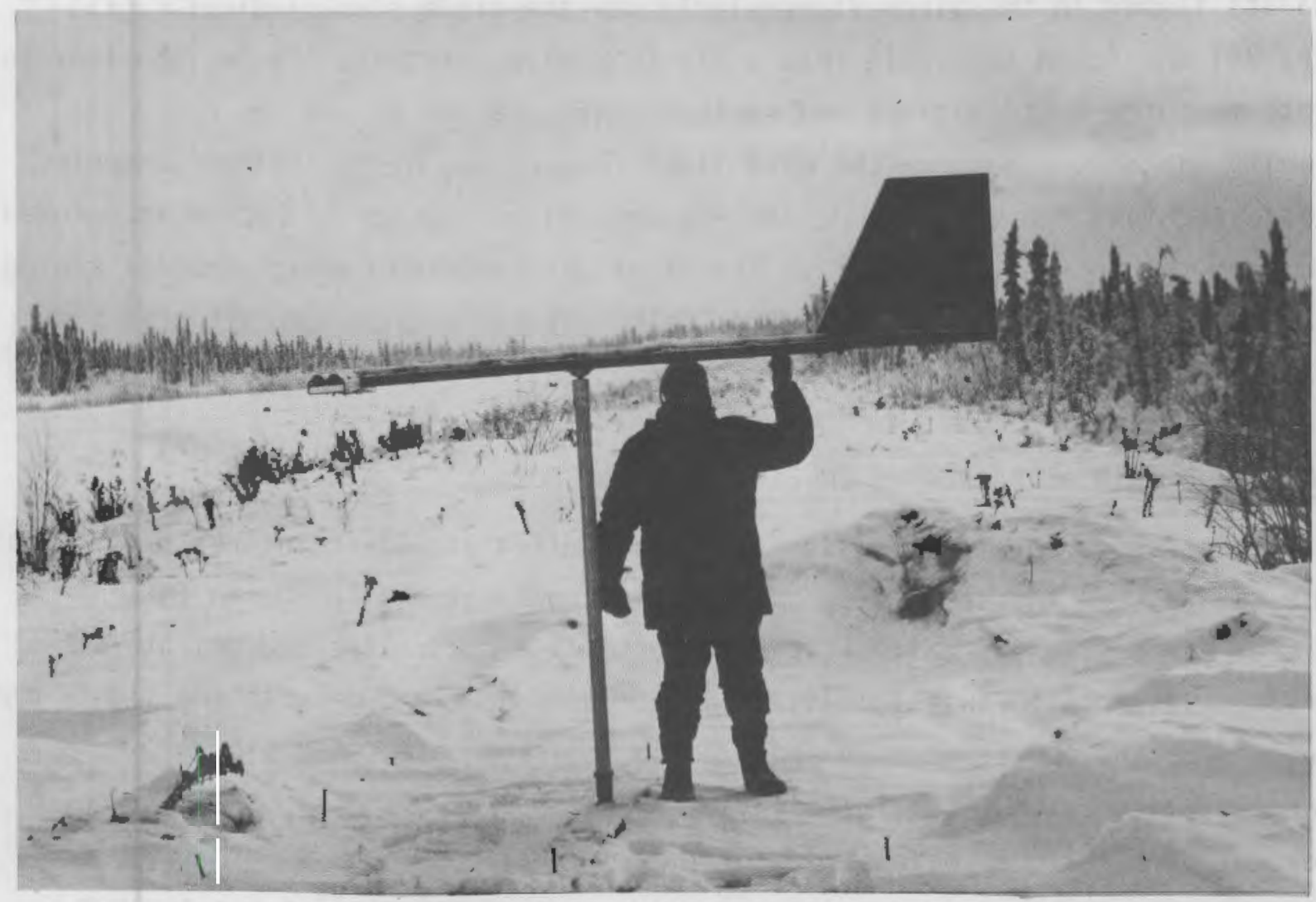

FIGURE 8. Radioluminescent Light Wind Indicator 
clearly visible from more than $1-1 / 2$ miles away and was difficult to use beyond $1 / 2$ mile. RL lights for runway alignment were preferred over flare pots since night vision was not compromised. Use of alignment lights did not improve acquisition distance but significantly improved the ability to align the aircraft earlier than with edge lighting only. Flare pots were found to be visible from about $50 \%$ further than RL lights. Neither flare pots nor RL lighting was acceptable as a navigational aid, but the strobe light (which is visible from 7 to 11 miles) was entirely usable for this purpose. The reliability and permanent nature of RL lighting make it an overwhelming choice over flare pots as a landing aid.

One evening of testing was devoted to evaluating several VASI configurations. The glide slope indicators (Figure 9) were positioned $500 \mathrm{ft}$ down the runway with $10 \mathrm{ft}$ between front racks (when two vertical racks were used) and $57 \mathrm{ft}$ between the front fixture and the back fixture. The pilots judged all systems from $1 / 2$ to 2 miles away. The DOT\&PF observer and one of the FAA pilots flying in the aircraft regularly saw the glide slope indicator (Figure 9d) and found it usable from $1-1 / 2$ to 2 miles distant. It is important to note that the most distinct and easiest configuration to use was not necessarily the ones producing the most light (Figure $9 a, b, C$ ). Pilot comments indicated that the $\mathrm{L}$ configuration (Figure $9 \mathrm{~d}$ ) was easier to become accustomed to than the top hat (Figure 7). The pilot who reported having problems seeing and using the glide slope indicators felt that his astigmatism affected his $v$ ision enough to reduce $h$ is acquisition and ability to use the system.

\section{TAXIWAY LIGHTS AT FAIRBANKS INTERNATIONAL AIRPORT}

Blue superwand taxiway lights were installed at 150-ft intervals on one of the taxiways on the south side of the main runway at the Fairbanks International Airport. This taxiway is used by small air carriers and private aircraft. Response to this installation was good; however, because the lights are quite dim, the 150-ft spacing appeared to be inadequate. Additional lights were supplied by ORNL for installation on the runway. The support fixtures of several of the lights were struck by snow removal equipment or other vehicles; however, the lights were not damaged and have been reinstalled for further testing. 

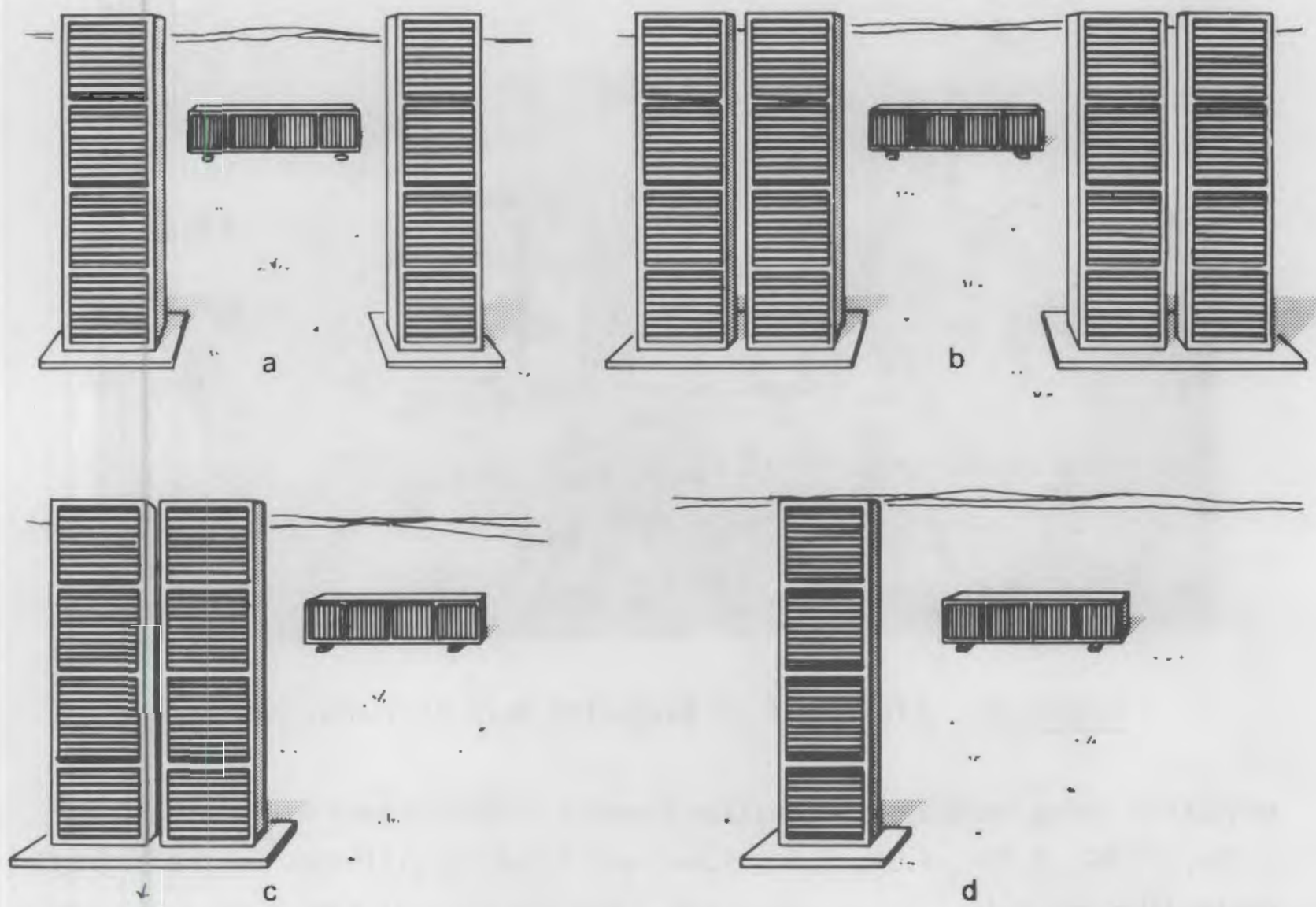

FIGURE 9. Configurations of Glide Slope Indicators Evaluated

\section{RL LIGHTING TESTS AT HANFORD ARID LANDS ECOLOGY (ALE) RESERVE}

RL lighting panels incorporating the newer tritium tube design developed by ORNL were evaluated at the ALE Reserve near Richland, Washington. Some of the support fixtures were those designed for the 1983-84 Alaskan testing. As a result of static and photographic evaluations, a new support fixture was designed for flight evaluations conducted near Richland, Washington, during late September and early 0ctober 1984 (Figure 10).

Using the older fixtures, the lights were evaluated photographically and visually using Rattlesnake Ridge on the Hanford ALE Reserve to simulate elevations and flight pattern locations encountered by pilots during base and final approaches. The action plan for this work is presented in Appendix $C$. Two rumway lighting configurations and three glide slope indicator designs were 


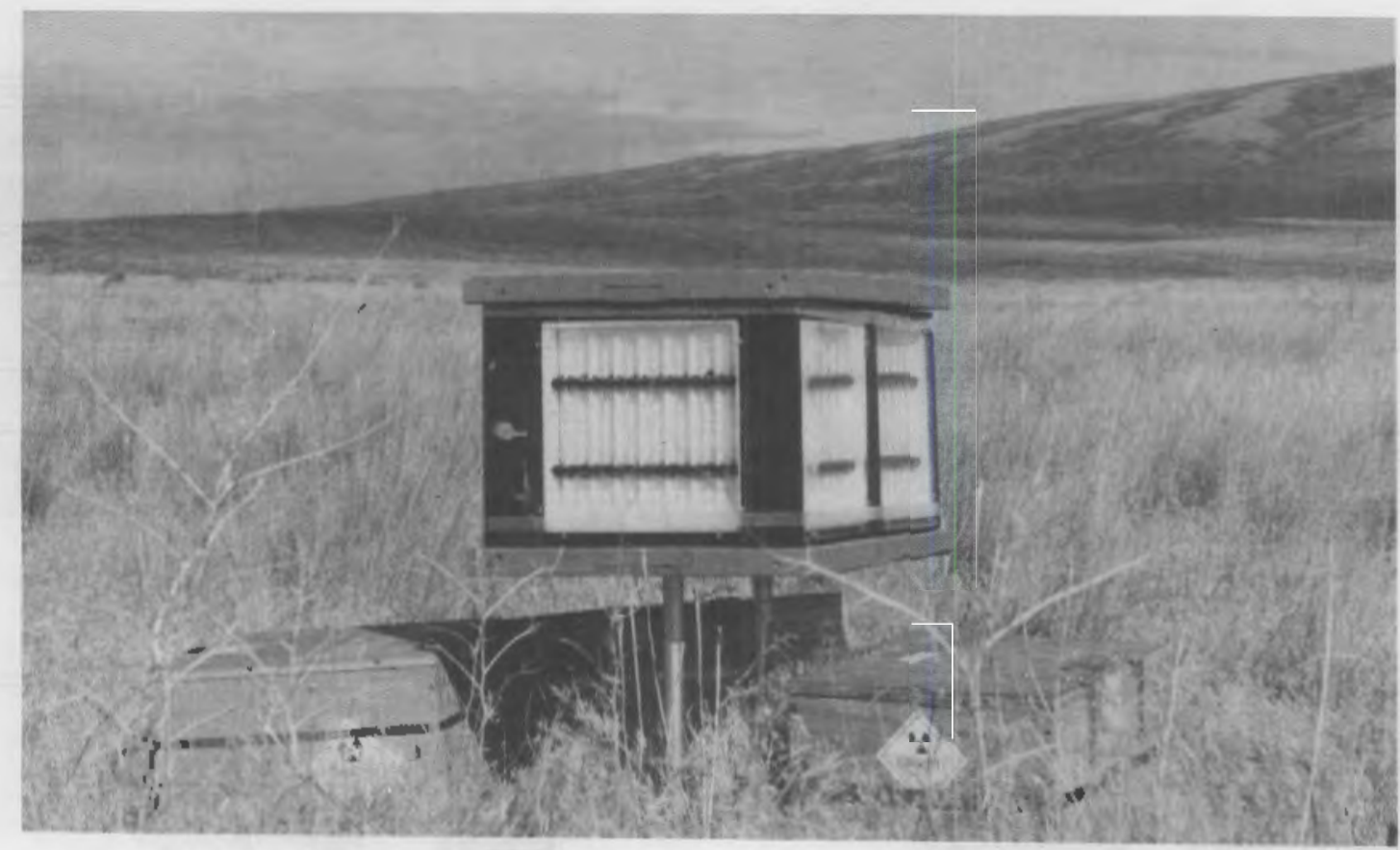

FIGURE 10. Light Fixture Evaluated Near Richland, Washington

evaluated using roadways to simulate runways. Photographs were taken from $0.33-, 0.65-, 0.77-, 1.0-, 1.4-, 1.5-$, and 1.9-mile distances on the runway centerline and 0.48-, 1.1-, 1.4-, 1.6-, and 1.8-mile distances at a $25^{\circ}$ angle to the centerline to simulate the base leg of the approach. Elevations above the runway were chosen to simulate the elevation the pilot would be above the runway using a $3^{\circ}$ approach angle during descent.

Over 100 photographs were taken; five typical photographs, taken at distances of $0.33,0.77,1.0,1.5$, and 1.9 miles, are presented in Figures 11 through 15. Additional work was performed using photographic techniques to determine the received light density at various locations. These data are being evaluated and will be used with photometric measurements of individual panels to model the field of light density at different locations. This information will be used to develop a computer simulation to train pilots and other users of the lights.

\section{SUMMARY OF DEMONSTRATIONS AND EVALUATIONS}

The information obtained in the military and civilian testing in Alaska during 1984 and findings of these tests can be summarized as follows: 
- Acquisition distance of tritium RL lights ranged from 2 to 5 miles for civilian pilots and from 3 to 6 miles for military pilots, with some pilots reporting acquisition at greater distances.

- Runway definition occurred for civilian pilots from 1 to 3 miles and for military pilots at distances of 2 to 6 miles.

- Alignment $c$ an be enhanced using runway alignment (lead-in) lights; the use of these extra lights may be more effective than increasing the light emission from the threshold area.

- A navigational aid, such as a strobe light, is needed to lead civilian pilots to the airfield. Once the pilot is in the vicinity of the dirfield, the RL lights are a good landing aid.

- FAA flight standards pilots evaluating the lights felt that they could be used with operator specifications and pilot training. A reliable wind indicator and a beacon or strobe as a navigational aid are needed.

- The lights worked well in Alaska under the weather conditions of the tests. More testing may be needed (for example, in fog, rain, or other conditions) before full FAA approvals are given. Maintenance was minimal and only involved cleaning once in a while and snow removal. Thin (less than 1/16-in.) hoarfrost layers on the light cover enhanced light output. Evaluation of thicker layers of hoarfrost is needed to clearly define problems from this phenomenon.

- An improved glide slope indicator is needed. The top hat configuration (Figure 9) was somewhat confusing and difficult to use. Evaluation of an L-shaped configuration showed promise, but further work in this area is needed.

- Blue RL lights show promise for taxiway purposes. A closer spacing than the normal $150 \mathrm{ft}$ is probably required unless the light output can be improved.

- Pilot vision may be important. This factor was identified by one of the FAA flight standards pilots and is supported by the lower response of older pilots as compared with younger observers in the aircraft. 


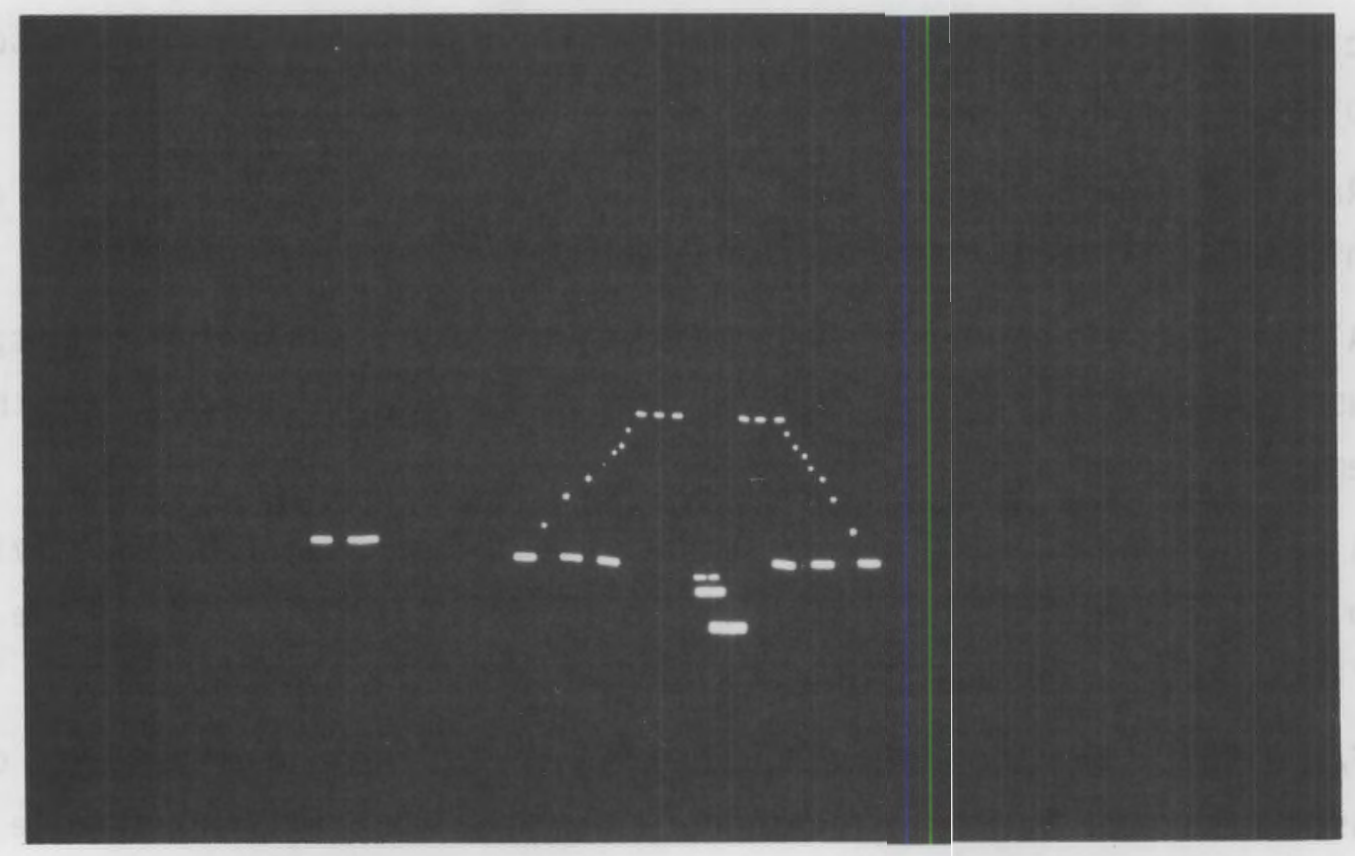

FIGURE 11. Typical Photograph Taken at a Distance of 0.33 Mile from RL-Lighted Runway

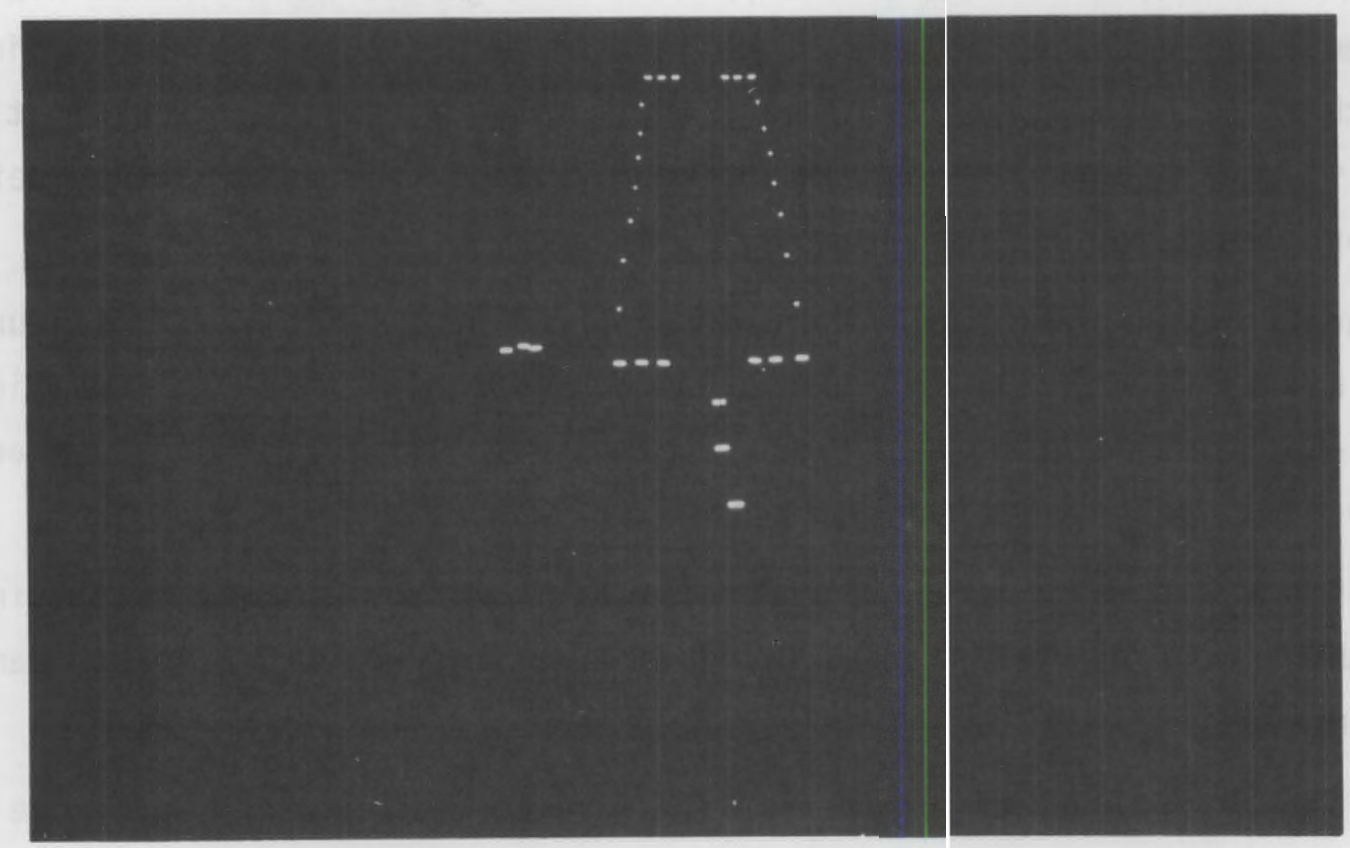

FIGURE 12. Typical Photograph Taken at a Distance of 0.77 Mile from RL-Lighted Runway 


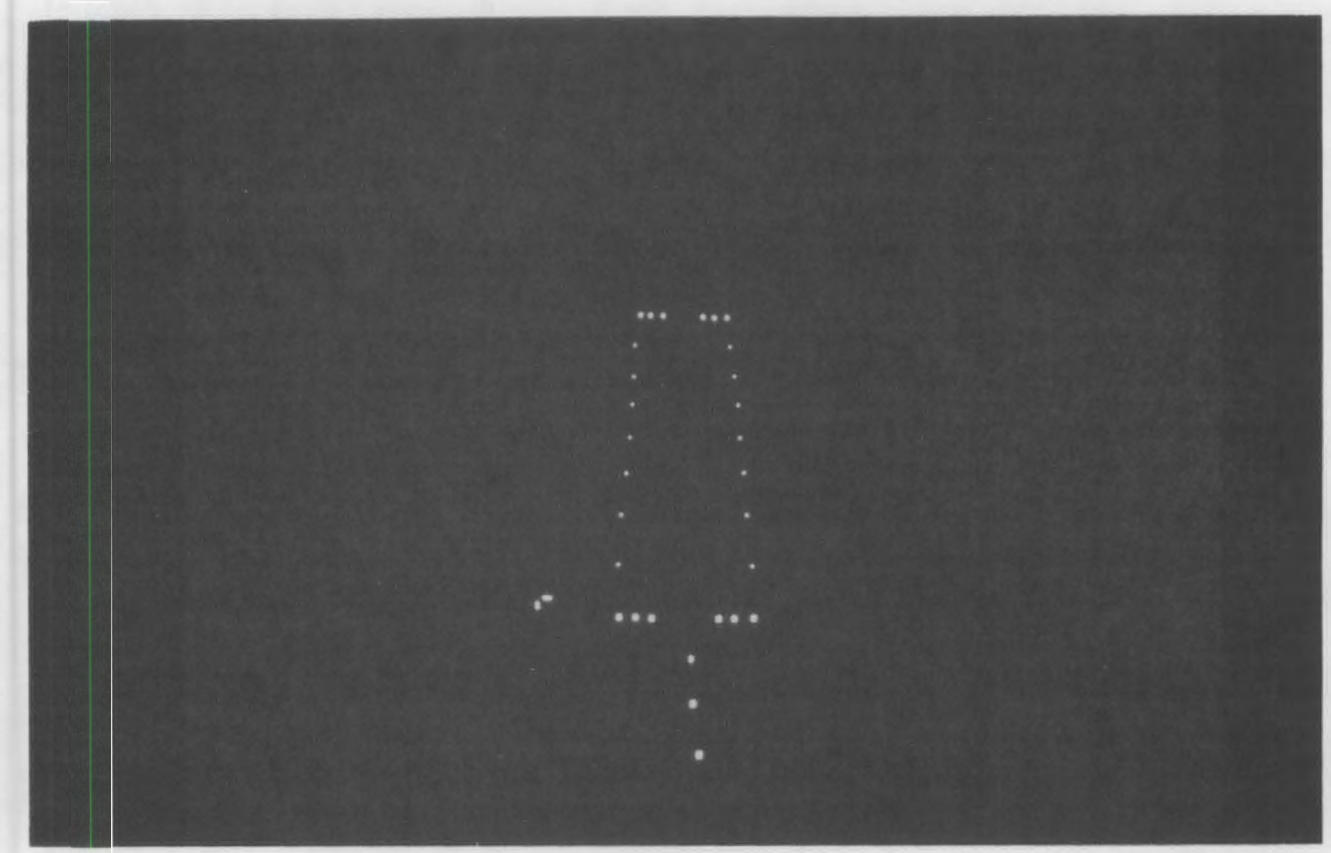

FIGURE 13. Typical Photograph Taken at a Distance of 1.0 Mile from RL-Lighted Runway

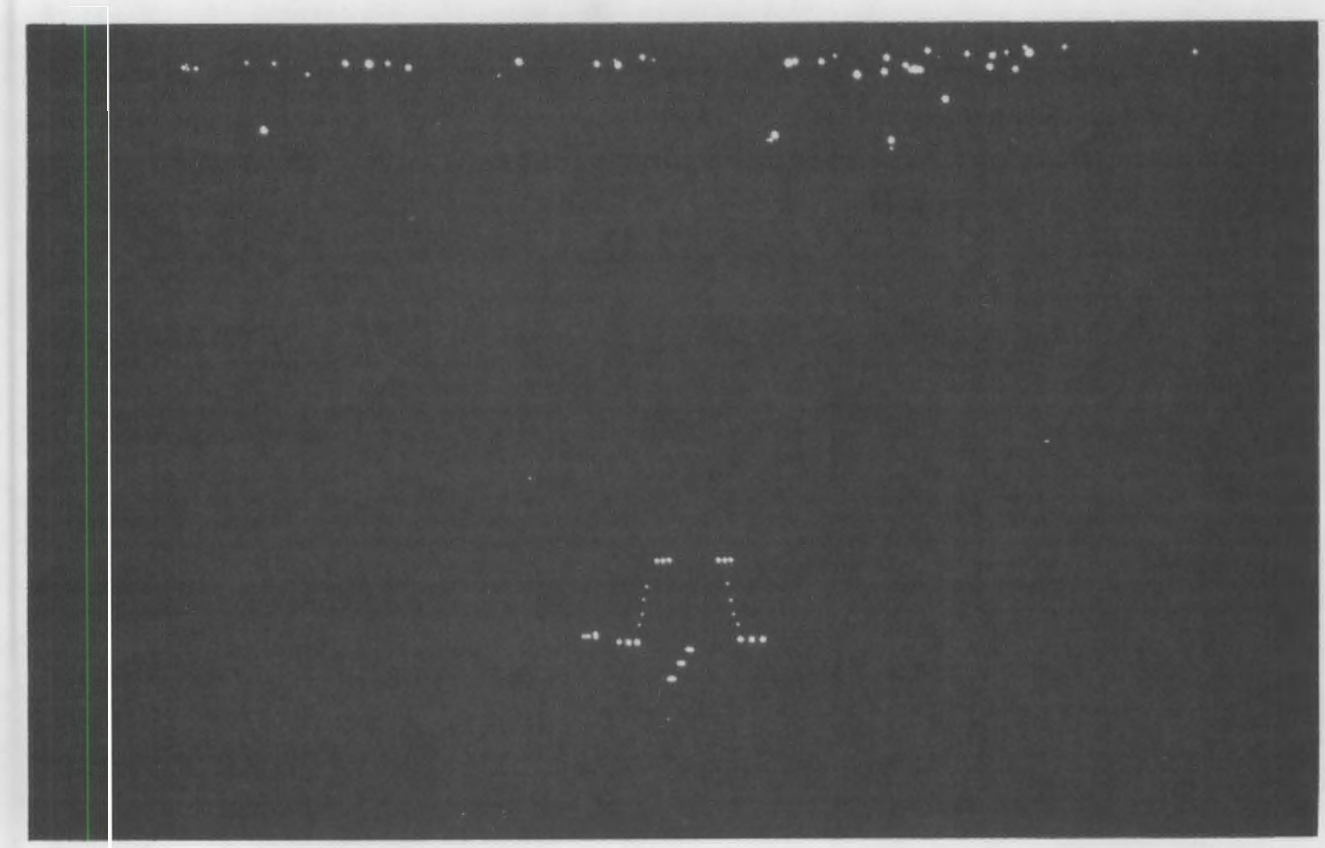

FIGURE 14. Typical Photograph Taken at a Distance of 1.5 Miles from RL-Lighted Runway 


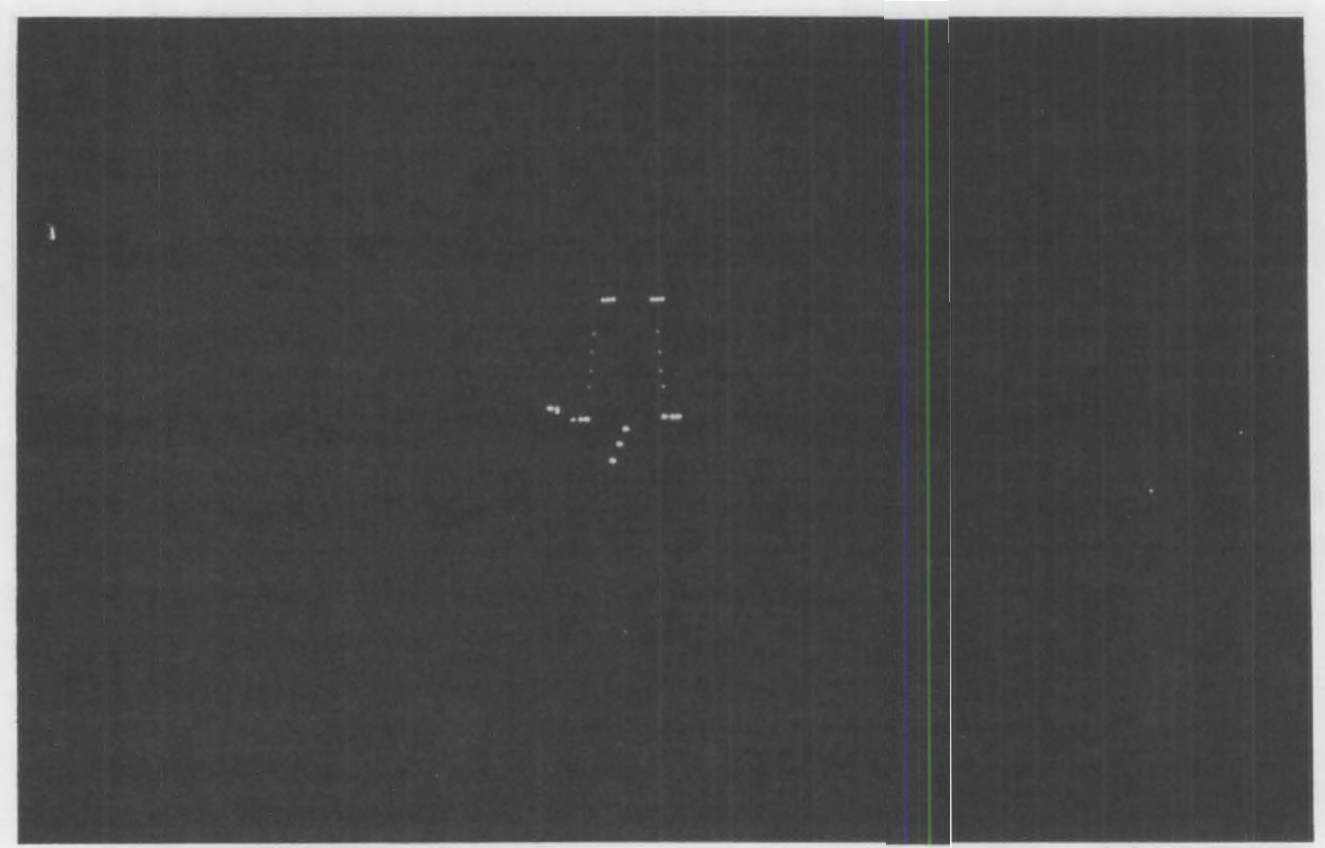

FIGURE 15. Typical Photograph Taken at a Distance of 1.9 Miles from RL-Lighted Runway 


\section{ISSUES AFFECTING RL LIGHTING SYSTEM USE IN ALASKA}

Issues affecting the use of RL lighting systems in Alaska include: cost, acceptance and utility of the system, and regulatory and FAA approvals.

$\operatorname{COST}$

The installed capital cost of a conventional MIRL system presentiy ranges from as low as $\$ 100,000$ to as much as $\$ 300,000$ in rural Alaska. ${ }^{(3,8)}$ This high and variable cost is due mostly to the degree of remoteness of the airport and the complexity of providing a suitable electric power source. Maintenance costs for MIRL systems currently installed in Alaska are also very high and can exceed the original capital cost in a very few years.

$\mathrm{RL}$ lighting systems suitable for rural Alaskan applications are expected to have an installed capital cost ranging from $\$ 80,000$ to $\$ 150,000 .(3,8)$ This estimate reflects the present cost of tritium of approximately \$1.10 per curie. Thus, the estimated installed cost may be less than that of a conventional system. Maintenance and operation costs for RL systems over the system's lifetime are estimated to be less than $35 \%$ of the original capital cost, substantially reducing the total cost.

Market potential will be affected by the supply and cost of tritium. Currently, the supply of tritium is limited and costs are relatively high. If a tritium supply were available to produce the lighting systems identified in Table 4 with the idea that volume sales would result in lower prices, capital costs for runway lighting would be reduced substantially.

\section{ACCEPTANCE AND UTILITY OF THE SYSTEM}

At the present time, a prototypic RL airport lighting system exists that is effective and useful. The system has been evaluated in Alaska and elsewhere, and refinements that must be made to the bas ic concepts of fixture design, materials use, etc., have been identified. In Alaska, those needs are primarily for durable and low-cost systems in a package that is acceptable to 
TABLE 4. Possible Implementation Schedule (per year basis)

\begin{tabular}{|c|c|c|c|c|c|}
\hline T ime & $\begin{array}{c}\text { Number of } \\
\text { Conventional } \\
\text { Systems } \\
\text { Installed }\end{array}$ & $\begin{array}{l}\text { Number of } \\
\text { RL Systems } \\
\text { Insta!led }\end{array}$ & $\begin{array}{c}\text { Number of } \\
\text { Conventional } \\
\text { Systems Replaced/ } \\
\text { Modified with RL }\end{array}$ & $\begin{array}{l}\text { Number of } \\
\text { RL Sys tems } \\
\text { Upgraded/ } \\
\text { Modified } \\
\end{array}$ & Iritium, $k C i$ \\
\hline $\begin{array}{l}1985-1986 \text { ith FAA } \\
\text { Part } 135 \text { approval }\end{array}$ & 3 to 5 & 3 to 5 & 0 & 0 & 200 to 500 \\
\hline $1987-1989$ & 3 to 5 & 3 to 5 & 0 & 0 & 200 to 500 \\
\hline $\begin{array}{l}1990-1992 \text { with } \\
\text { full FAA approval }\end{array}$ & 0 & 5 to 10 & 2 to 5 & 2 & 500 to 1500 \\
\hline $1993-1995$ & 0 & 10 to 15 & 5 to 10 & 3 to 5 & 1500 to 2500 \\
\hline $1996-2000$ & 0 & 15 to 20 & 10 to 15 & 10 to 20 & 2500 to 3900 \\
\hline
\end{tabular}

the appropriate regulatory agencies. The health and safety factors related to the lights have been reviewed by several organizations, and published results indicate that the environmental hazards of using the lights for runway applications are minimal. $(2,9,10)$

\section{REGULATORY APPROVALS}

For RL. airport lighting systems to flourish in Alaska, two main regulatory considerations must be addressed:

- Users, such as the State of Alaska, would prefer to minimize their involvernent with the regulatory process. Thus, suppliers and/or manufacturers would be expected to obtain general licenses from the U.S. Nuclear Regulatory Commission on any RL products they wish to sell in Alaska.

- RL airport lighting systems in Alaska and elsewhere need to be accepted by the FAA as an alternative to conventional lighting systems for appropriate applications. FAA acceptance would ensure product acceptance and, perhaps most importantly, would qualify the RL products to be specified on federal aid projects. 
FEDERAL AVIATION REGULATIONS PART 135 APPROVAL

The RL system must receive operational exposure in Alaska if the potential benefits are to be realized. In the civilian sector, state and FAA cooperation is needed to permit use, though perhaps 1 imited at $f$ irst, of the system by air taxis in a passenger-carrying operation. This process could begin with the Regional FAA Flight Standards Authority in Alaska, who could develop a policy and action plan that would permit use of RL lights under $P$ art 135.229 of the FAR as an alternative to flare pots or lanterns. The demonstrations and tests conducted at Central, Alaska, during January and February 1984, an FAA evaluation completed at Richland, Washington, during September and early October 1984, and military testing are a start in the approval process. 



\section{REFERENCES}

1. Haff, K. W., J. A. Tompkins, and F. N. Case. 1983. Evaluation of Arctic Test of Tritium Radioluminescent Lighting. ESL-TR-82-35, 0ak Ridge National Laboratory, Oak Ridge, Tennessee.

2. Oak Ridge National Laboratory. 1984. Tritium Radioluminescent Lighting Development. Presented at Technology Transfer Conference, March 2 T-22, T984, Oak Ridge, Tennessee.

3. Jensen, G. A., et al. 1984. Examination of the Feasibility for Demonstration and Use of Radioluminescent Lights for ATask an Remo te Runway Lighting. PNL-5783, AK-RD-84-16, Pacific Northwest Laboratory, Rich Tand, washington.

4. Wilson, E. J., and J.D.H. Hughes. 1960. "Light Sources Using Radio isotopes." Contemporary Phys. 1(1):62-69.

5. Niemeyer, R. A. 1970. "Tritium Loss from Tritium Self-Luminous Aircraft Exit Signs." Isotopes and Radiation Technology 7(3):349-352.

6. Lederer, C. M., and V. S. Shirley, eds. 1978. Table of Isotopes. 7 th ed. Wiley-Interscience, New York.

7. McElroy, J. L., and J. A. Powell. 1984. Nuclear Was te Management Semiannual Progress Report, April 1983 Through September 1983. PNL-4250-4, Pacific Northwest Laboratory, Rich land, Washington.

8. Leonard, L. E. 1984. "Radioluminescent Lighting Applications in A laska." State of Alaska, Department of Transportation and Public Facilities, Division of Planning/Research Section, Fairbanks, Alaska.

9. General Electric. 1977. Table of 1sotopes. San Jose, California.

10. Moghissi, A. A., and M. W. Carter. 1975. "Public Health Implications of Radioluminous Materials." U.S. Department of Health, Education, and Welfare, Food and Drug Administration, Rockville, Maryland. 


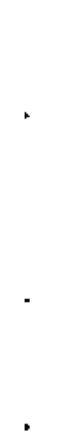


APPENDIX A

SUMMARY OF CIVILIAN PILOT RESPONSES - CENTRAL, ALASKA 
Name:

Aircraft

Location:

Contact phone:
DOTKPF RESEARCH

OBSER VER QUEST IONNAIRE TRITIUM LIGHT CONF IGURATION SUMMARY OF PILOT RESPONSES
Return to:

Leroy Leonard

DOT RPF Research

23 lo Peger Road

Fairbanks, AK 49701<smiles>[C]1CC1</smiles>

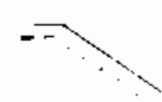

1. At what distance from dirport did you first acquire lights? <l Mi l l-2 Mi $5 \quad 2-3 \mathrm{Mi} \quad 9 \quad 3-4 \mathrm{Mi} 10>4 \mathrm{Mi} 2$

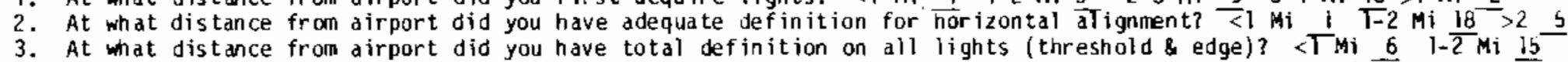

4. In the traffic pattern, were you able to maintain reference to the runway? Yes 23 No 3 Maybe

5. Did the down-wind corner markers help in maintaining reference while in the traffic pattern? Yes $\overline{23}$ No 1 Mayte 3 6 . Was the wind direction indicator adequate? Yes $\ldots \underline{2}$ No 23 Maybe 1 Comments

Ambient Lighting Conditions: Moonlit: Yes 3 No 9 Twilight or day 13

Cloud Cover: Thin/scattered 13 Broken 1 Overcast 8

Ceiling Height$$
\text { AGL }
$$

Precipitation: 5now

Fog_l Haze

2 None 13 
Name:

Date:

Aircraft:

Location:

Contact phone:
DOT\&PF RESEARCH

OBSERVER QUESTIONNAIRE

TR ITIUM LIGHT CONFIGURATION

SLIMMARY OF PASSENGER RESPONSES
Return to:

Leray Leonard

DOT\&PF Research

2310 Peger Road

Fairbanks, AK $99 \%$

$=$
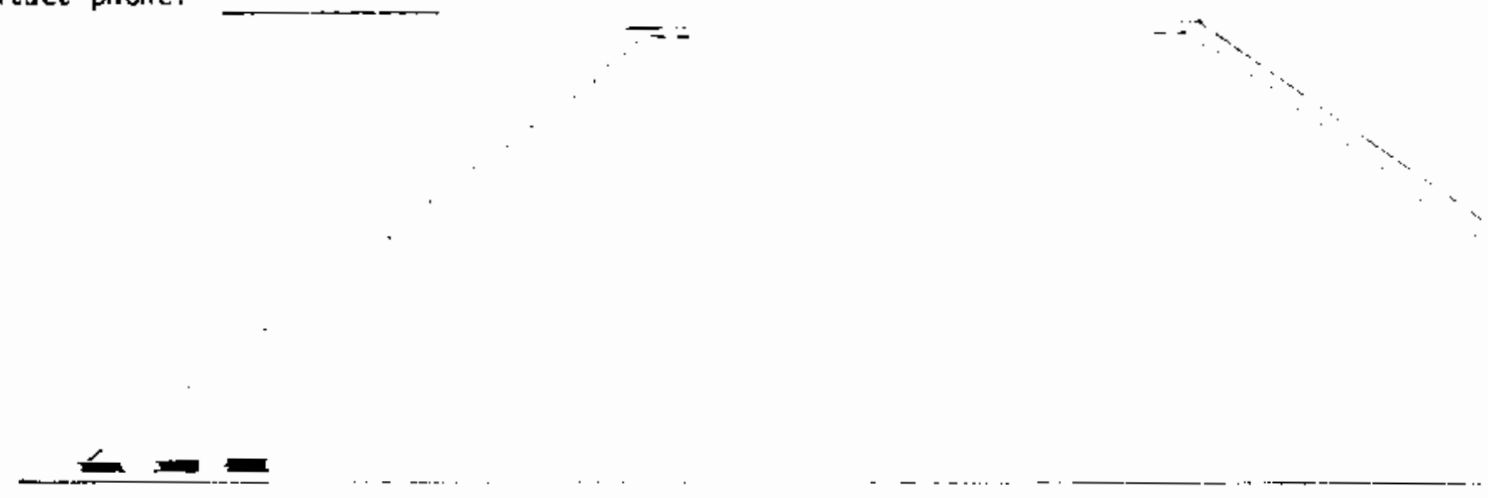

1. At wat distance from airport did you first acquire lights? $1-2$ ini $\frac{5}{2-3} \mathrm{Mi} \quad 2 \quad>3 \mathrm{Mi}$

2. At what distance from airport did you have adequate definition for horizontal alignment? $<1 \mathrm{Mi} 2 \quad 1-2 \mathrm{Mi} b 32 \mathrm{~b}$

3. At that distance from airport did you have total definition on all lights (thresnold\& edge)? $<T M i 2$ l- 2 Mr 7

4. In the traffic pattern, were you able to ma intain reference to the runway? Yes 3. No 1 Mayoe

5. Did the down-wind corner markers help in maintaining reference while in the traffic pattern? Yes 4.4 No 5 Maybe 6. Was the wind direction indicator adequate? Yes No 11 Maybe Comments

Ambient Lighting Conditions: Moonlit: Yes _ove No
Cloud Cover: Thin/scattered

Ceiling Height AGL Precipitation:- Snow Fog.

haze None 
APPENDIX B

NEW YEAR'S EVE 1983 EVACUATION CORRESPONDENCE 


\title{
Dejlieserviges
}

Po Box 9

$1 / 1 / 34$

\author{
Acting Comissioner Glenn Glenzer \\ DOTPF \\ Pouch $\mathrm{z}$ \\ Juneau, Ar: 90211
}

Dear Mr. Glenzer:

A.s you ere aware, the runway here at Central is the site of the experinent this winter of the trittun vapor lights. As a rural commity, we are watching this experinent with interest, for we can really appreciate what its success can mean to a bush area.

On llew Year' $E$ EVc, we had occasion to see first-hand how helpful the lights wore. An evening fire destroyed the home of Ancers Eergssen (who, by the way, is a retired DOTPF employee). In attents to control the fire, Mr. Bergssen was painfuliy burned on his hands, hoad and back. Lue to the nature of the injuries and the fear that he right go into teef shock, we requested a Nedivac evacuation to get him to Fairbanks and nedical attention. Conaltions were only fair between Fairbanks and central, but Hedivac attenpted the flight and were successiul in getting the patient to Fairbanks. It was a good feeling to be able to tell then that the runway had the iritiun vasor lights--and to know, in case they vere unable to get over the mountains from Fairbanks, that we had an alternative in case it would be necessary for one of the local pilots or air services to try the flight fron here, that on acecuately lighted ranray wes available.

As comilunities like Central and circle kot Springs do hot have available the more extensive local clinic facilities that many native villages in the bush have, the importance of a lighted runwey for energency nedical evecuations often becornes a prime factor. As you can inagine, wany folks here at central hope the experinent becomes a peimanent part of our locel runkay.

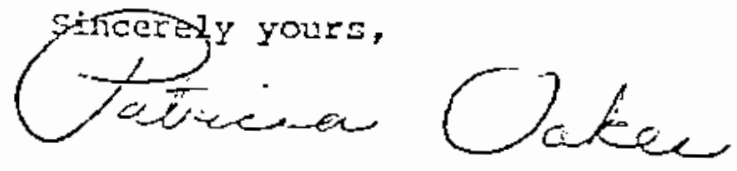

l:iss Patricia Oakes

cc: Kasry Suret

CONSULTANT SERVICES:

Ruraleducational Pianning, Curriculum $\&$ Instruction LlaskatlstorvRescarch $\&$ Review
B. 1

GEHERAL SERVICES:

Resaarch, Editing 2 PublicRolations

Mobila Secrefarialsarvico-Matary Publis 


\section{MEMORANDUM State of Alaska}

TO

Glen Glenzer, Acting Commissioner Department of Transportation

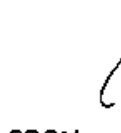

FROM

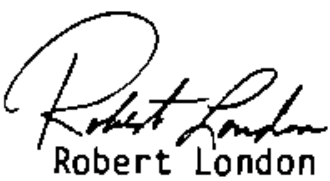

$\operatorname{limit}_{2}$

Robert London Smith, Commissioner

Department of Health and Social Services
DATE: February 2, 1984

FILE NO

TELEPHONE NO

SUBJECT:

Tritium Lights at Airfields

Attached, for your information, is a letter from Dr. David Lam, Senior Flight Surgeon with the U.S. Army Medical Department at Ft. Wainwright. Or. Lam says he is extremely impressed with the tritjum lights which have been placed at the airfield in Central, and he suggests that this project be expanded to small, isolated airfields throughout the state.

Our State Emergency Medical Services plan calls for emergency lighting for runways in small villages to facilitate medical evacuations during periods of darkness, and perhaps tritujm lights can provide a viable solution to this problem.

You may want to contact Or. Lam to further discuss this matter.

cc: Governor William Sheffield
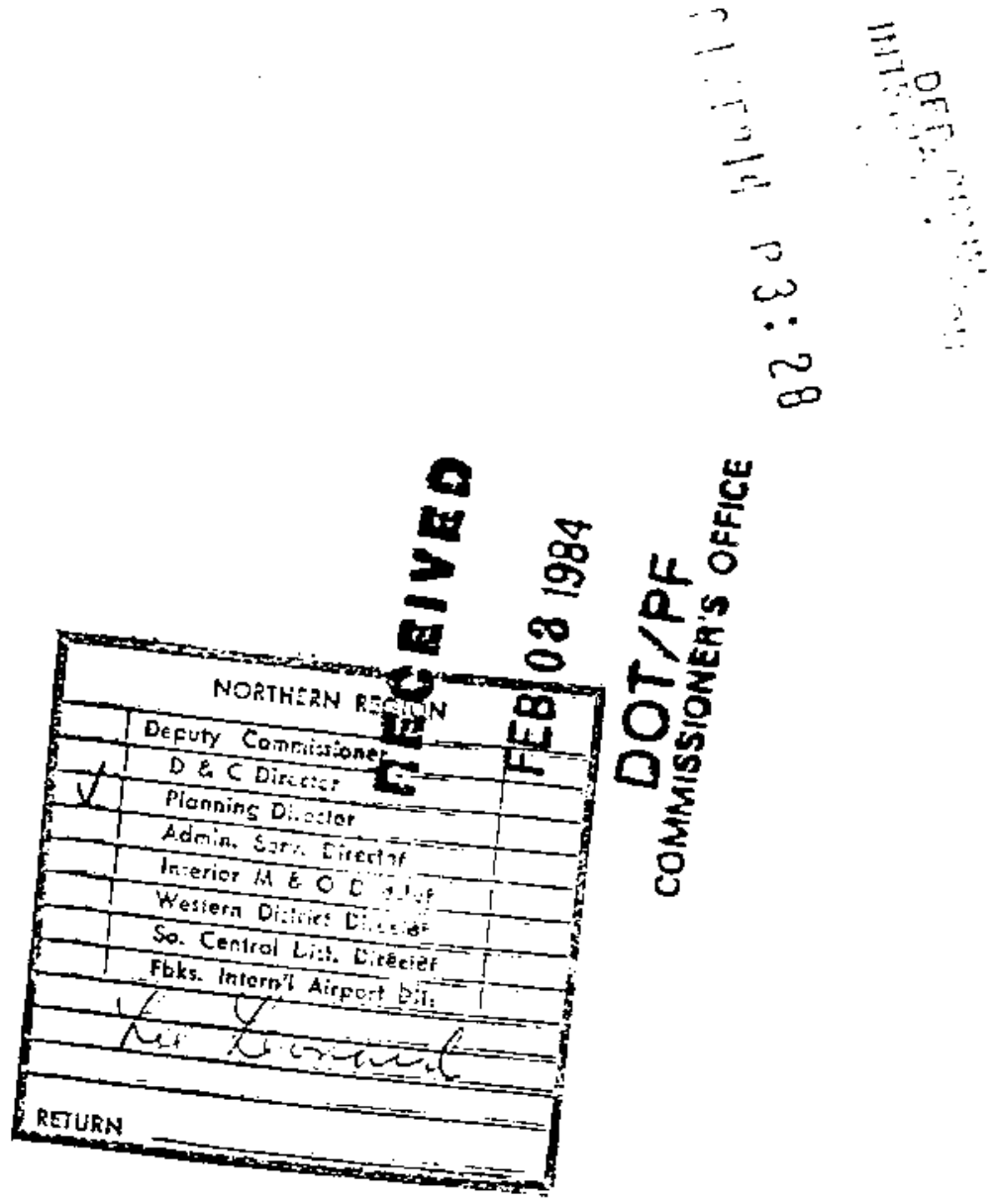

B. 2 


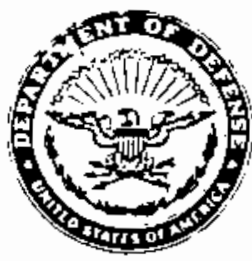

DEPARTMENT OF THE ARMY

HEADQUARTERS. US ARMY MEDICAL DEPARTMENT ACTIVITY IALASKAI

FORT WAINWRIGHT. ALASKA 99703

mertrio to

January 20,1984

Office of the Commander

Mark Johnson

EMS Coordinator

State of Alaska

Department of Health and Socjal Services

Pouch $\mathrm{H}-06 \mathrm{C}$

Juneau, Alaska 99811

Dear Mark:

I greatly appreciate your offer to attempt to obtain funding for my trip to Anchorage on Wednesday to attend the State Medevac Task Force Meeting. As I said, normally I will be able to combine those trips with some of the other many duties that I have in Anchorage and therefore am normally able to utilize military aircraft for transportation, but in this case I was unable to. The total cost as depicted on the Travel Authorization Form attached was one hundred and fifty two dollars. If you can help me out in this respect, it would be much appreciated.

In general terms, as regards the air ambulance regulations, I like and concur with the recomnendation made by John Hall that we include four specific levels of certification; one to be an advanced life support carrier (the so-called flying intensive care unit), one a basic life support carrier which could be staffed and equipped at a lower level of expertise, one general authorization for any of the major air carriers who may have to carry a patient so long as the patient's transport is arranged and coordinated through either the airlines medical department or private physicians knowledgeable in air evacuation requirements, and the fourth should be a specific authorization to use any type of aircraft whether or not it is ambulance-equipped in an emergency.

Additionally iust for your infomation. I would annreciate it if you would mention it to anvone you know in the Department of Iransportation that the tritium. linhts that they have oliced at thamirfieic at Central, Alaska for field markinos aro extromely effective on New Years Eve lad the opportunity to fly up there in a blinding spous stom to plak up a civilian who had gotten burned. The lights were visible for a significant period of cume oetore we reached the tield and they were of

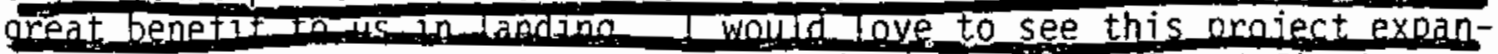
ded throughout the entire state to all of the smailisolated fields.

I am still checking on the cost and availability of the air evacuation liquid oxygen device and the on-board oxygen generating system which we have mentioned at the last couple of meetings. When I get more information from the Air Force I will certainly keep you informed. 
Just for your information I did send into Governor Sheffield several months ago an application for appointment to the Advisory Committee on Emergency Medical Services. To date I have not yet heard whether the application has been accepted but I'm still hoping to be with you at the next meeting.

Thanks again for all of your help. I am certainiy enjoying working with you on this project.

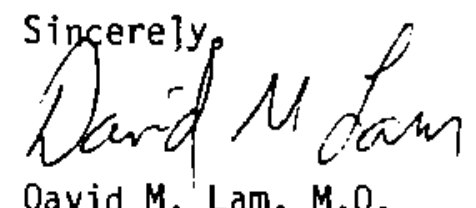

Oavid M. Lam, M.O.

Lieutenant Colonel, Medical Corps, Senior Flight Surgeon

Commanding 


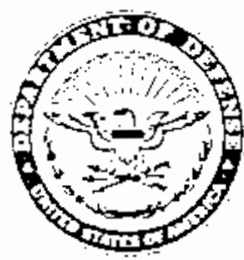

DEPARTMENT OF THE ARMY

222D AVIATION EATTALION ICBTI

FORT WAINWRIGHT. ALASKA 99703

January 18,1984

28ヨd Medical Detachment

Mr. Leroy Leonard

DOT/PF Research

2302 Pegar Road

Fairbanks, Alaska 9970I

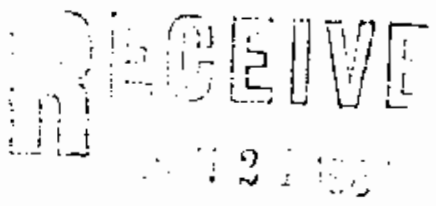

DOTPF COSEQRCH SE

Dear Mr. Leonard:

I read Everett Long's recent article in the news miner pertaining to Radio Luminescent $\left\{R-L_{y} y\right.$ Lights at Central. My comments will begin with answers to the questions posed at the end of his article.

Pilots name is MAJ John $\mathrm{N}$. MCNair. The aircraft used was a UH-LV air ambulance helicopter. Weather during the approach to Cantral was ceiling none, visibility 2 miles with haze, night. I approached the airport from the southwest at approximately b000 msl. The first light I saw was the strobe on a maintenance shed. It could be seen before even the outline of the village. The runway lights were clearly visible from about 2 miles out. On a clearer night they possibly could have been seen from a greater distance. Runway reference was not a problem in the landing pattern. Except for the green color, the lights were as good as any low intensity runway lights. I did not note the wind toe or corner markings during my operations there. In addition the runway was covered with about six inches of fresh, powdery snow. I landed short of the location of the vehicles which were meeting us and skiied up the runway in a snow cloud between the lights. The R-L lights served as excellent markers for taxiing in the blowing snow conditions.

It is my opinion that these $R-L$ lights are a godsend to a small landing strip. The ambient light level in the night $I$ went to central was nil. The landing at the strip was certainly much safer because of the presence of the $R-L$ Iights. I suggest that these lights be installed at all village landing strips. Certainiy if they save a few lives from landing short accidents or running off the runway, they would be worth the expense. My hat is off to the fellow who came up with them.

If you have any further questions about my flight to central please call me at $353-6292$.

Sincerely,

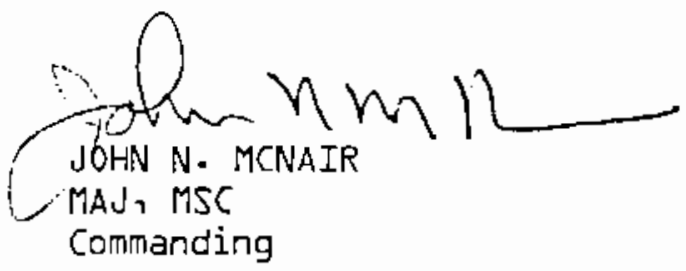




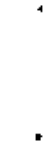


APPENDIX C

PHOTOGRAPHIC EVALUATION ACTION PLAN 


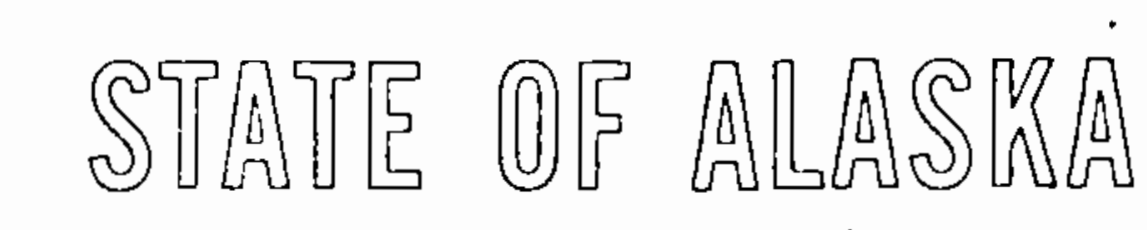

DERARTMENT OF TRANSPORTATION AND PURLIC FACILITIES

DIVISION OF PLANNING ANO PROGRAMMING

RESEARCH SECTION

April 19, 1984
Bill Sheffield, Governor

2301 Peger Road

Fairbant:s, Alaska 99701.6394

Prone: 9007 ) 479.224i

lír. 8ill Remini

Program Manager

ByProduct Utilization

Office of Defense Waste \&

ByProduct Management

U. S. Department of Energy

llashington, D.C. 20545

Dear Bit1:

fittached is the action plan for collecting photographic data which we have previously discussed. I'm sure there will be several modifications to this plan due to Timitations in the field, but I think the basics of the plan can be successfully executed. Please let me know if anyone has any questions.

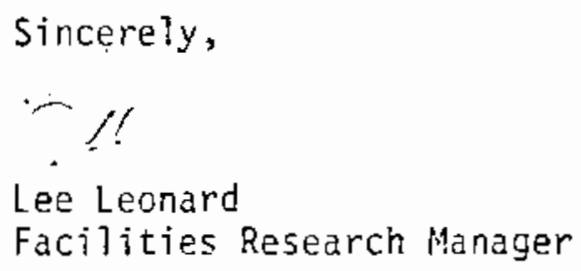

Einc

Attachment

cc: D. Erown, Oak Ridge Nationa 1 Laboratory, Oak Ridge, Tit

L. Everett, Lt. Col., NC-ARNG, Horrisville, NC

U. Haff, Oak Ridge National Laboratory, Oak Pidge, Tli

T. Härdy, Headquarters, AFESC/ROLS, Tyndali AFB, FL

G. Jensen, Battelle Pacific Morthwest Laboratory, Ricinland, kA 
PHOTOHETRIC DATA COLLECTION

ACTION PLAN

PLACE: U. S. Department of Energy Hanford Reservation, Hanford, WA.

TIME: $\quad$ Apri1 28, 1984 - May 7, 1984

ORGANIZATION:

The field crew will rendezvous at Pacific Northwest Laboratory (PNL) on April 27, 1984: The late afternoon will be devoted to meetings and briefings by PNL staff regarding the physical terrain and the logistics of the field work. Saturday and Sunday, April 28 and 29, will be spent preparing field sites for deployment. Some of the micro data (see below) may be gathered on Aprit 29. On Honday, April 30, the Moon will be new and deployment of lights for Macro data collection will begin and will continue on succeeding nights until the complete data inventory is collected. It is anicicipated that all of the necessary data can be obtained by Hay 6.

\section{PERSOHNEL:}

The following individuals have expressed interest in participating in this exercise and will make up the field crew:

1. Andy Thompkins - Oak Ridge National Laboratory

2. George Jensen - Pacific Northwest Laboratory

3. Bob Moles - Pacific Northivest Laboratory

4. Lee Leonard - Alaska 0ept. of Transportation and Public Facilities

5. Janet Strid: - Alaska Dept. of Transportation and Public Facilities

6. Technicians from Pacific irorthest Laboratory

7. Pnotographic Staff 
This list is not intended to exclude anybody. Any TWG members are welcome and encouraged to participate, however, for planning purposes the above list has expressed their specific intention to attend as of this date.

\section{DATA TO BE COLLECTED}

\section{MICRO DATA:}

Single RL light units (wands and panels) will be compared to calibrated light sources at various distances using still photography in 35 $m \pi, 21 / 4 \times 21 / 4$, and $4 \times 5$ formats. These data will be used for reference, calibration of macro photographic data and for the quantitative comparison to produce a computer simulation of a RL system. Micro data will be gather each night of observation as a calibration check on each night's photography.

\section{MACRO OATA:}

The macro data to be collected will consist of still photographs takan of various $R L$ airfield lighting configurations. Using the natural terrain and elevation changes available on the Hanford reservation to produce a vantage point. Three data sets per configuration will be collected simulating the reference required when operating VFR night within the rumby environment. These are:

\section{Downind ieg path.}

2. Ease leg turning point.

3. Final approach path.

Proposed observation patls for the simulation are shown in figure 1. Location of distinct observation points along each of the three paths are specified in tine table. The specific locations of these points has been deterilined to encompass a data set which will best relate to the critical 
visual keys required by pilots using an RL system. Observations along the final approach path will include observations of various VASI configurations. In a11 cases the $12^{\prime \prime} \times 12^{\prime \prime} \mathrm{RL}$ unit panels will be used as edge lights on $400 \mathrm{ft}$. spacing. The inventory of runway end markers, VASI's, and lead-in light configurations which we intend to photograph is shown in Figure 2. The total data set will include about 100 photographs. However, since a number of exposure settings and formats are desirable perhaps 300 to 600 photographs will be collected. 
TABLE 1

Photographic Simulation Data Set

\begin{tabular}{|c|c|c|c|c|c|}
\hline Point & $\begin{array}{c}\text { Observation } \\
\text { Path }\end{array}$ & $\begin{array}{l}\text { Distance } \\
\text { From } \\
\text { Threshold } \\
\text { in Niles }\end{array}$ & $\begin{array}{l}\text { Altitude } \\
\text { in Feet }\end{array}$ & $\begin{array}{l}\text { Route } \\
\text { Speed } \\
\text { in } \\
\text { Knots } \\
\end{array}$ & Viewing Orientation \\
\hline 1 & Downuind & .25 & 500 & 70 & 81 \\
\hline 2 & Downwind & .5 & 600 & 85 & \\
\hline 3 & Downwind & .75 & 600 & 100 & \\
\hline 4 & Downwind & 1.0 & 900 & 130 & \\
\hline 5 & Downwind & 1.5 & 1000 & 130 & \\
\hline 6 & Downind & 2.0 & 1000 & 150 & 36 \\
\hline 7 & Base & 0.5 & 150 & & $y$ \\
\hline 8 & Base & 1.0 & 300 & & \\
\hline 9 & Base & 1.5 & 500 & & \\
\hline 10 & Base & 2.25 & 600 & & \\
\hline 11 & Base & 3.25 & 800 & & \\
\hline 12 & Base & 4.125 & 1000 & & \\
\hline 13 & Final & 0.25 & 70 & & \\
\hline 14 & Final & 0.5 & 140 & & \\
\hline 15 & Final & 0.75 & 200 & & \\
\hline 16 & Final & 1.25 & 350 & & $\omega$ \\
\hline 17 & Fina? & 1.75 & 500 & & \\
\hline 18 & Final & 2.5 & 700 & & . \\
\hline 19 & Final & 3.25 & 1000 & & \\
\hline $2 C$ & Find & 4.0 & 1000 & & \\
\hline
\end{tabular}




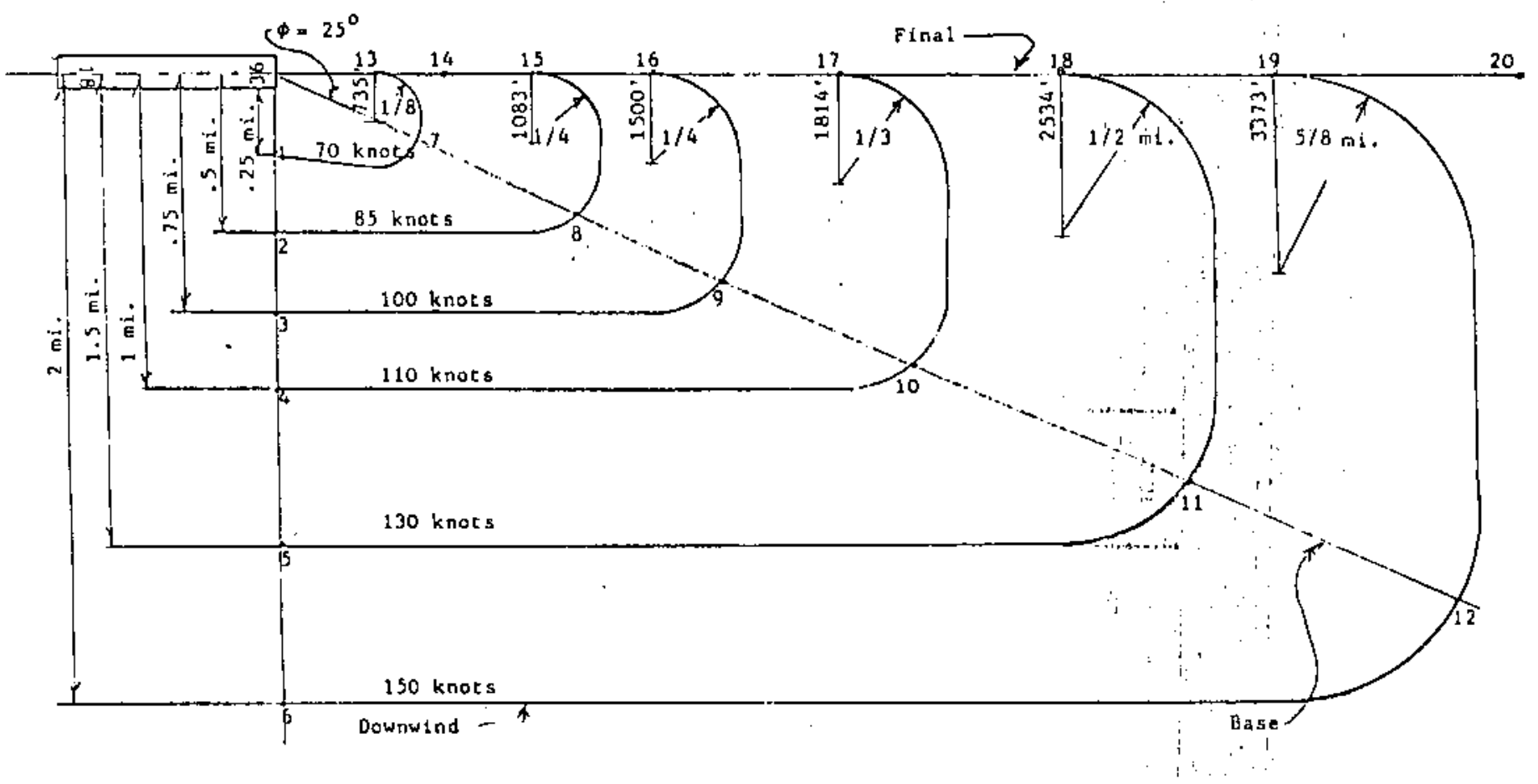

Figure 1: Data Point Diagram 


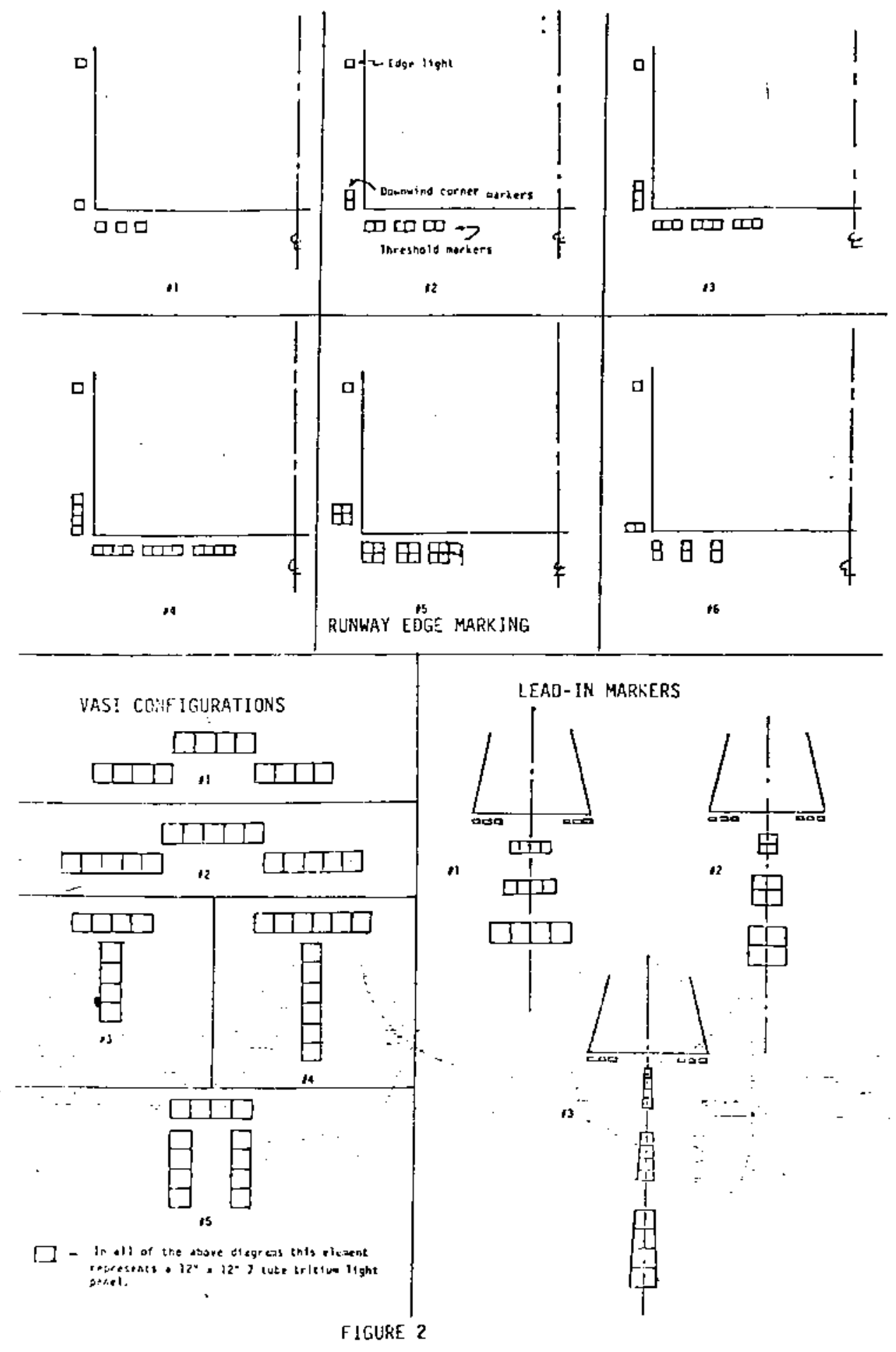

c. 7 
4 


\section{DISTRIBUTION}

No. of

Copies

OFFSITE

2 L. E. Leonard

State of Alaska DOT\&PF

2361 Peger Road

Fairbanks, AK 99708

L. Hegdal

State of Alaska DOT\&PF

2361 Peger Road

Fairbanks, AK 99708

W. C. Remini

R\&D and Byproducts

U.S. Department of Energy

Washington, OC 20545

J. J. Jicha, Jr.

$R \& D$ and Byproducts

U.S. Department of Energy

Washington, DC 20545

30 DOE Technical Information Center

K. W. Haff

P.0. Box $X$

Oak Ridge National Laboratory

Oak Ridge, TN 37830

E. Lamb

P.0. Box $X$

Oak Ridge National Laboratory

Oak Ridge, TN 37830
No. of

Copies

ONSITE

4 DOE Richland Operations Office

M. Dayan i

H. E. Ransom

J. L. Rhoades

J. D. White

2 Battelle-Alaska Operations

L. D. Perrigo

40

Pacific Northwest Laboratory

S. K. Edler

C. R. Hann

P. E. Hart

J. H. Jarrett

G. A. Jensen (26)

J. L. McElroy

A. M. Platt

G. L. Tingey

Publishing Coordination (2)

Technical Information (5) 


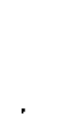

